\title{
La tragicomedia, un problema sin resolver de exégesis aristotélica*
}

\author{
Luis Sánchez Laílla \\ Universidad de Zaragoza \\ lsanlai@unizar.es
}

Recepción: 26/03/2019, Aceptación: 20/07/2019, Publicación: 04/12/2019

\section{Resumen}

La aparición de la obra Il pastor fido con la denominación de "tragicomedia» provocó un encendido debate teórico entre los defensores de este género, no contemplado en la Poética de Aristóteles, y sus detractores. Algunos de los argumentos empleados por unos y otros tuvieron su reflejo en las controversias que en torno a la comedia nueva se generaron a principios del siglo Xviı en España, donde la obra de Guarini fue bien conocida. Sin embargo, y a pesar de que la comedia nueva fue asimilada desde el principio a la tragicomedia, no hubo en España un ejercicio sistemático y coherente de análisis teórico, desde postulados aristotélicos, tanto para su justificación como para su refutación, similar a la polémica entre el propio Guarini y Giason Denores. La comparación entre las ideas de estos autores y las de Francisco de Cascales y otros teóricos aristotélicos españoles contemporáneos, ponen en evidencia las limitaciones del pensamiento literario en España.

\section{Palabras clave}

teoría literaria; tragicomedia; Giambattista Guarini; Compendio della poesia tragicomica; Giason Denores; Cascales; Tablas poéticas

\footnotetext{
* Este trabajo se ha realizado en el seno del Grupo de Investigación de la Universidad de Zaragoza «Edición y estudio diacrónico de la literatura hispánica» (H-04_17R), reconocido por el Gobierno de Aragón.
} 


\begin{abstract}
Tragicomedy, an unsolved problem of Aristotelian exegesis

The publication of $I l$ pastor fido with the subtitle of "tragicomedy" provoked a strong theoretical debate between the defenders and the opponents of the new genre, not treated in Aristotle's Poetics. Some of the arguments that were used by ones and the others had an impact on the controversies about the comedia nueva in the early $17^{\text {th }}$ century in Spain, where Guarini's work was well known. Nevertheless, despite the fact that the comedia nueva was soon assimilated to tragicomedy, Spain did not develop a systematic and coherent analysis, on Aristotelian basis, in order to justify or refute it, similar to Guarini's polemic against Giason Denores. The comparison between the ideas of these two authors and those of Francisco de Cascales and other contemporary Spanish Aristotelian theorists shows clearly the limitations of literary thought in Spain.
\end{abstract}

\title{
Keywords
}

Literary theory; tragicomedy; Giambattista Guarini; Compendio della poesia tragicomica; Giason Denores; Cascales; Tablas poéticas

Está por hacer una historia completa de las polémicas generadas por la aparición de Il pastor fido de Giambattista Guarini, adscrito a la denominación genérica de tragicomedia, y de su reflejo en la literatura espańola; no solo por lo que respecta a su recepción y su utilización como fuente de inspiración en obras españolas, sino a la adopción de los argumentos teóricos desarrollados por el poeta italiano para justificar este parto de su ingenio, monstruoso a los ojos de los estudiosos más apegados a las enseñanzas aristotélicas, a los que podemos denominar con el término de preceptistas en su sentido más recto. Un estudio comparativo riguroso de ambas experiencias literarias, con más conexiones en el plano teórico de las que en principio pudiera sospecharse, arrojaría nueva luz sobre este capítulo clave de nuestra historia literaria.

La oportunidad de este trabajo viene motivada por las carencias y también por las virtudes de nuestro pensamiento literario aurisecular. La reflexión sobre el arte de escribir comedias y demás géneros escénicos fue en España considerablemente 
más pobre, no solo en cantidad, sino en calidad, que en Italia, verdadera metrópoli intelectual del mundo en la Edad Moderna. Sobre esto no merece la pena insistir: podemos darlo por bueno, como han hecho todos los críticos, y pasar a otra cosa. Sin embargo, si se repasa la literatura crítica pertinente, uno no acaba de saber muy bien a qué se debe esta inferioridad canonizada. Estamos ante una paradoja. La tradición filológica española ha tendido más a la aceptación sumisa que al contraste, quizás porque cada vez que se ha intentado la comprobación empírica de los datos descritos, los resultados se han empeñado en corroborar lo que muchas veces no eran sino intuiciones de inteligentes lectores. La bibliografía da buena cuenta de los innumerables plagios, reinterpretaciones o translaciones directas por parte de nuestros pensadores de los autores italianos - Escalígero en Pinciano; Robortello en el Arte nuevo de Lope; o Minturno y Robortello en Cascales- Pero ¡cuál es la diferencia cualitativa verdaderamente significativa entre unos y otros, por lo menos en cuanto a los géneros dramáticos se refiere? Desde luego no lo es el conocimiento de la tragedia y el desarrollo de una teoría sobre el género aristotélico por excelencia. No cabe duda de que los españoles de este tiempo conocieron bien la Poética del filósofo griego, tan bien como llegaron a conocerla los italianos, puesto que en buena medida fue un conocimiento transmitido y compartido.

La solución hay que buscarla, a mi juicio, por otros derroteros. El análisis de los documentos teóricos españoles, sobre todo los grandes - Pinciano, Cascales o Carvallo-, demuestra la pericia de estos autores para interpretar, glosar y contrastar con la realidad las nociones literarias tomadas en consideración; pero saca también a la luz las limitaciones para afrontar las innovaciones literarias que trae el cambio de siglo. Y aquí entra en juego un capítulo fundamental de la literatura dramática espańola y europea: la comedia nueva, auténtica hidra escénica, que devoró géneros en cuestión de años causando general admiración y desconcierto. Si todavía hoy sigue desbordando a una legión de filólogos, pertrechados de modernos conceptos teóricos y teorías interpretativas, podemos comprender el desamparo que debieron sentir los intérpretes de nuestro Siglo de Oro, cuya única arma era un pensamiento aristotélico, ya sin filo a fuerza de blandirlo a diestro y siniestro. Pero es que, además, la aparición de la tragicomedia como nueva manifestación literaria, no contemplada por Aristóteles, señala el principio del fin de la Poética como texto básico de referencia en todo acto creativo. ${ }^{1}$ Estas circunstancias son especialmente notorias en España, donde los teóricos dieron muestra de una evidente incapacidad o impotencia para dar explicación a un fenómeno dramático que, sin embargo, fue intuido como auténtica tragicomedia, y como tal fue combatido o defendido.

Durante muchos años ha imperado un cierto localismo en la interpretación de fenómenos literarios considerados específicamente españoles, como es el caso

1. A ello apunta Lope de Vega cuando declara, a propósito de Aristóteles, que «ya le perdimos el respeto" (Arte nuevo, v. 190). 
de la comedia nueva. Pero, considerado en el conjunto de la producción tragicómica a la que asiste el final del siglo xvi en Italia, el teatro nacional español se reviste de nuevos significados, y los preceptistas italianos nos suministran explicaciones o soluciones a los problemas teóricos planteados que los españoles no encontraron, o no lograron plantear convenientemente.

Desde luego, no hay nada comparable en España al riguroso ejercicio de defensa de la tragicomedia Il pastor fido de Giambattista Guarini por parte de su propio autor, llevado a cabo desde presupuestos rigurosamente aristotélicos, que es el asunto central de este trabajo. Su elección nos permite establecer un contraste concreto y muy significativo entre las literaturas críticas italiana y espańola. En Italia, al contrario de lo que sucedió en España, hubo un intento de elaborar una teoría de la tragicomedia que abarcase el nuevo género en su totalidad, tratando de dar respuesta a todos y cada uno de los problemas planteados por sus diferentes facetas. $\mathrm{Y}$ vamos a tratar de ver de qué forma esas mismas preguntas y esas mismas respuestas tienen su reflejo solo de forma esporádica y fragmentaria en el pensamiento literario español de la época.

\section{La tragicomedia como problema nuclear del siglo XVII}

\section{La tragicomedia, género limitrofe. El drama pastoral y la comedia nueva, especies de un género común. Ecos de la tragicomedia italiana en España. Defensores y detractores de un monstruo literario}

El siglo XVI se presenta a los ojos del estudioso de la literatura como un hervidero de problemas de teoría literaria al que dan lugar los numerosísimos comentarios de la Poética de Aristóteles. La mímesis, la catarsis, lo maravilloso, la naturaleza moral de la Poesía o la oposición entre universal poético y particular histórico son algunos de los aspectos que van ocupando el interés de los tratadistas y los escritores en distintos momentos y a raíz de determinados acontecimientos literarios. A estos asuntos más generales se unen los que atañen a la definición de los géneros, que es uno de los campos más ricos e interesantes de la teoría literaria renacentista.

Sin embargo, en este trabajo, quiero centrar mi atención exclusivamente en un aspecto, de entre todos los posibles, propiamente teórico y relativo a la cuestión de los géneros, como es el de la tragicomedia. La aparición de la tragicomedia como nuevo género a finales del siglo XVI y principios del xvII produjo algunas de las polémicas más acres. Su trascendencia radica en su carácter «limítrofe» entre distintos géneros, en cuanto que, como ya he dicho, provocó una crisis en la auctoritas de la Poética como sustento explicativo de toda la creación literaria, y acabó convirtiéndose, como advierto en el epígrafe de ese apartado, el auténtico problema nuclear.

En España no faltaron los reflejos para asumir las cuestiones planteadas por la eclosión de nuevos géneros dramáticos —el drama pastoral en Italia y la comedia nueva en España; la tragicomedia como problema de fondo en ambos-a 
finales del siglo XVI y muy próximos además en el tiempo. Pero lo cierto es que las dificultades se plantearon en primer lugar en Italia por la aparición de una serie de obras que tuvieron rápidamente difusión europea. Me refiero al Aminta de Torcuato Tasso (Venecia, Aldo Manuzio, 1581) y a Il pastor fido de Guarini (Venecia, Battista Bonfadino, 1589), ambas descritas por sus autores como «favole boschereccie» —es decir, fábulas de los bosques, término que las sitúa en el ámbito de la literatura pastoril, de amplia difusión en las literaturas romancesy, en el segundo de los casos, subtitulada como "tragicomedia pastorale». ${ }^{2}$

Apenas me voy a referir a la primera de ellas, Aminta, porque, a pesar de su altísimo valor literario, no deja de ser un antecedente de la obra de Guarini, que supo captar y profundizar en los valores del modelo, y fue una obra de menor repercusión más allá de las fronteras italianas. Por otro lado, ambas se integran en una tradición todavía más ańeja en Italia y no ajena a nuestra literatura que es la de los coloquios pastoriles, la misma que en la que hunden sus raíces las églogas de Juan del Encina. El universo de la literatura de pastores es complejísimo, como muy bien ha estudiado López Estrada (1974), y se ensanchó por géneros diversos, en prosa o en verso, en el ámbito de la lírica o de la narrativa o del drama, pero nunca se pudo obviar ese principio germinal del diálogo entre pastores, al que bastaba suministrar unos medios mínimos de representación —unos actores y un escenario- para convertirse en un auténtico género dramático.

Realmente bastaba con eso, como se puede ver en Aminta, donde asistimos a los amores contrariados del pastor que da título a la obra y Silvia, y donde los valores propiamente dramáticos se nos antojan muy escasos, habida cuenta de que tan apenas hay acción. Ninguno de los acontecimientos esenciales - y eso que hay algunos tan dramáticos como un suicidio frustrado - se produce en escena, sino que son narrados en diálogos entre los distintos personajes, dando lugar a duplicaciones, simetrías y puntos de vista cruzados sobre los mismos hechos, método compositivo que luego utilizaría Cervantes con tanto aprovechamiento. Lógicamente, son los valores de la palabra poética los que van a asegurar la pervivencia de Aminta.

Esta dramatización se hizo constante en el marco de las cortes renacentistas italianas, en gran parte porque el dulce coloquio entre estos refinados pastores servía de vehículo para conceptos y valores de gran predicamento entre miembros de estos círculos aristocráticos. Por un lado, se sugería una escena natural, un modelo de vida pura y de sentimientos espontáneos que suponía una evasión de las ilusiones del mundo cortesano, dando cuerpo al tópico del menosprecio de corte y alabanza de aldea, y, por otro, se idealizaban los aspectos más frívolos y hedonísticos de la vida en la corte, de forma que las representaciones teatrales se convertían en pretextos mundanos para la expresión libre de los sentimientos amorosos. El público cortesano se recrea en esta época en la moda de las «cuestiones de amor» a la italiana por influencia del Filocolo de Boccaccio, que tiene su reflejo en el teatro popu-

2. Para un estudio monográfico del drama pastoral italiano, véase Sampson (2006). 
lar con los coloquios de Lope de Rueda (Oleza Simó 1984). Porque el teatro popular y el teatro cortesano no fueron nunca compartimentos estancos; de hecho, para Oleza, el teatro de origen palaciego se vio obligado a salir a la calle para ganar la batalla al teatro populista e italianizante y, a causa de esta apertura al gran público, se produjeron una serie de fenómenos literarios que podemos denominar de «transición» a la comedia. Mediante el análisis de églogas publicadas o representadas en Valencia en la segunda mitad del siglo XVI, ya mostró cómo se evolucionó del primitivo «juego literario de salón» a obras cada vez más complejas, en las que se combinan los patrones rústicos de la égloga, los modelos bucólicos virgilianos y las primeras manifestaciones de la comedia nueva.

En este contexto en el que se mezclan la ficticia espontaneidad del universo pastoril y el extremo artificio cortesano se produjeron las representaciones de Aminta y de Il pastor fido. La primera en el palacio de los duques de Este de Ferrara - epicentro de otros patrones literarios relacionados con la épica, o la heroica, como dice el Pinciano- y la segunda en la suntuosa corte de los Gonzaga en Mantua, cuando ya se acerca el fin de siglo. Pero estas representaciones no se producían solo en Italia. Hoy sabemos del cultivo de la égloga en los teatros de la nobleza con ocasión de conmemoraciones, circunstancias políticas concretas o rituales cortesanos de distinta naturaleza. Representaciones que respondían a dos corrientes teatrales que confluyen: por un lado, los motivos cómicos y costumbristas de las viejas piezas litúrgicas, en las que los pastores tenían un papel destacado, sobre todo en las relacionadas con la liturgia navideña (Rodríguez Mancho 1984); y, por otro, la tradición culta de las églogas virgilianas, en las que damas disfrazadas de pastoras se abrían mutuamente el corazón y narraban sus platónicos amores (Oleza Simó et al. 1984). Y todo esto en ese periodo que coincide con el destierro valenciano de Lope y lo que viene a ser algo así como la prehistoria de su nuevo concepto de comedia según la ya vieja tesis de Rinaldo Froldi (1968).

No en vano, varias son las obras pastoriles del primer Lope, género por el que volverá a interesarse en torno a 1615, con la escritura de Arcadia, muy contaminado ya con esquemas formales y temáticos de la comedia mitológica. La huella de Il pastor fido es evidente en El verdadero amante - ya en el título, que es una acertada traducción-, comedia publicada en la Parte XIV (1620), pero que pudo ser compuesta a finales del siglo XVI —entre 1588 y 1595, según Morley y Bruerton (1968), y McGaha (1985), que es quien la ha estudiado con más detalle—, fecha que habla con claridad del caudal enorme de los flujos culturales entre España e Italia en este momento, si tenemos en cuenta la fecha de la primera edición de Il pastor fido. ${ }^{3}$ No obstante, no todo es influencia italiana y Schoell (1987) identificó en las obras pastoriles de Lope de Vega multitud de interferencias entrela herencia de las églogas castellanas de Encina y Lope de Rueda y el drama pastoral italiano de Tasso y Guarini.

3. Véanse a este respecto los trabajos de Trambaioli (2010a, 2010b y 2012) y Meunier (2018). 
En este punto, no está de más recordar algunos hitos de la recepción de este último. Podemos situar el comienzo de la fortuna crítica del poeta italiano en España en la traducción de Il pastor fido llevada a cabo por Cristóbal Suárez de Figueroa en Nápoles en 1602 —el mismo ańo de su publicación definitiva—, y alabada por Cervantes en la segunda parte del Quijote, cap. LXII, y por Gracián, tanto en la Agudeza como en El Criticón. Hubo otras dos traducciones posteriores de Pedro Patricio Mey (Valencia, 1609) — buena prueba de que por allí seguía vigente el gusto por este tipo de literatura - y de Isabel Correa (Amberes, 1641) — que estudió López Estrada (1994) por el interés de su prólogo para la teoría de la traducción-. Y como testimonio de que la obra de Guarini se convierte en un clásico europeo tenemos la versión en teatro de gran espectáculo que montan a mediados de siglo Solís, Coello y el mismísimo Calderón de la Barca (López Estrada 1989 y Trambaioli 2011).

Como vemos, Lope de Vega conocía las obras de Guarini, que imita en algunas de sus comedias pastorales, y probablemente conoció el contenido de su polémica con Denores, ${ }^{4}$ sobre la que hablaré a continuación, como la conocieron Ricardo del Turia y otros preceptistas españoles. Es cierto también que no se puede meter en un mismo saco la producción de ambos autores, Lope y Guarini, tan distinta en cuanto a su intención y a su concreción formal, pero los dos fueron progenitores de obras mixtas — «monstruos poéticos» para sus detractores en España y en Italia-, y sus partidarios emplearon con frecuencia los mismos argumentos a uno y a otro lado del Mediterráneo. La comedia nueva fue recibida e interpretada, o quizás sería mejor decir presentida, como tragicomedia ${ }^{5}$ su trascendencia es infinitamente mayor para el teatro moderno que las obras palaciegas de Guarini. No haberlo entendido así y omitir a España, salvo en asuntos anecdóticos, es la principal carencia del trabajo de Herrick (1962) sobre la tragicomedia, que es un clásico insoslayable. La obra de Margaret Newels (1974) fue el primer gran trabajo en que se puso en relación la comedia española y la doctrina clásica y moderna sobre la tragicomedia, con la inevitable pequeña historia de las polémicas que suscitó su implantación.

En España la discusión alcanzó una gran cantidad de matices y una difusión que hubiéramos podido calificar de universal, si no tuviéramos en cuenta la guerra desatada en el primer tercio del siglo Xviı por la poesía gongorina, con la que, según García Berrio (1980), el pensamiento literario español adquiere un liderazgo europeo. En Italia, sin embargo, la discusión en torno a la tragicomedia decayó rápidamente tras la publicación del Compendio de Guarini, como veremos enseguida, en parte porque este tratado fue un punto culminante en el debate sobre el género de Il pastor fido. La razón última, de todas formas, debemos buscarla en

4. Sobre este punto insisten Trambaioli (2010b) y Albalá Pelegrín (2013).

5. El rechazo al empleo del término tragicomedia en Lope de Vega, no impide que en el Arte nuevo identifique este género con la comedia nueva, «al menos en el marco de una aproximación teórica» (Couderc 2014: 69). 
el distinto horizonte de la escena en los dos países. Si en España la comedia nueva impone su dictadura hasta bien entrado el siglo XVIII, con un vigor insospechado y un éxito popular sin desmayos, los intentos teatrales de salón y corte - que no fueron otra cosa los resultados obtenidos por los literatos italianos-, sucumbieron ante una commedia dell'arte que era ya, por derecho propio, el auténtico teatro nacional italiano. Un drama allimprovviso, carente de reglas por naturaleza, en poco o en nada podía interesar a una mente aristotélica. A todo ello hay que añadir los intricados derroteros por los que la nueva poesía lírica, con sus oscuridades, había arrastrado a los preceptistas literarios también en Italia. Y mientras en España la comedia nueva acapara la reflexión en el siglo XviI en detrimento de la tragedia y otros géneros no dramáticos, en Italia, el poema heroico fue el campo en el que se libró la batalla definitiva para la que los preceptistas estuvieron afilando sus armas a lo largo de todo el siglo Xvi. La distinta naturaleza de las diversas literaturas nacionales y su estudio comparado tendrían también mucho que decir al respecto.

El asunto de la tragicomedia es, pues, tema casi exclusivo de reflexión a partir de 1617, fecha de la publicación de las Tablas poéticas de Cascales (Murcia, Luis Berós), a la cual podemos considerar última poética aristotélica española con vocación globalizadora. La actitud de Cascales en su condena de la tragicomedia no está lejos de la de sus colegas, sobre todo italianos. En Italia, sin embargo, el enfrentamiento entre partidarios y adversarios del nuevo género alcanzó unas dimensiones inauditas en otras partes de Europa. Este enfrentamiento dio lugar a escaramuzas intelectuales entre el propio Guarini, que no en vano era también profesor de poética y retórica, y del tratadista paduano Giason Denores, que son ilustrativas de la vitalidad que, tras un siglo largo de comentarios, seguía teniendo la Poética de Aristóteles.

Denores tiene su importancia para la historia de nuestro pensamiento literario, aparte de por el tema que nos ocupa, porque otra de sus obras, la Poética de 1588, es fuente comprobada de la Poética de Mártir Rizo — traducción o más bien comentario aristotélico inédito-, como estudió en su momento Nowicki (1973), demostración de la comunidad espiritual, por encima de fronteras, de los aristotélicos furibundos. En el caso de Mártir Rizo, amigo y colaborador de Suárez Figueroa, Torres Rámila y otros antilopistas, tuvieron en la escena española abundantísimos pretextos para dar rienda suelta a su integrismo literario.

Aparte del enfrentamiento directo de Giason Denores (1586 y 1590) con el propio Guarini $(1588,1593$ y 1599), muchos otros críticos tomaron la pluma en favor de uno o de otro: Lionardo Salviati (1586), Faustino Summo (1590 y 1601), Giovanfrancesco Alberti (1596), Paolo Beni (1600), Giovanni Pietro Malacreta (1600) y Orlando Pescetti (1601). ${ }^{6}$ Este episodio, dicho sea de paso,

6. La mayor parte de estos textos, junto con la Apologia in difesa del Pastor fido de Giovanni Savio, de fecha desconocida, están recogidos en la edición de las obras de Guarini por Giovanni Alberto Timermani (Opere, Verona, 1737-1738). 
todavía espera un cronista minucioso en el ámbito de la filología italiana, que vaya más allá del dato cronológico y vacíe en toda su riqueza los argumentos de propios y contrarios. ${ }^{7}$

Antes de avanzar en la materia, repasemos de manera sucinta las circunstancias de esta polémica.

\section{La polémica italiana en torno a Il pastor fido}

\section{Guarini contra Giason Denores, crítica práctica y modelos de debate humanistico}

En 1586 Giasone Denores da a la imprenta su Discorso intorno a qué principii, cause et accrescimenti che la comedia, la tragedia e il poema eroico ricevono dalla filosofia morale e civile, e da' governatori delle reppubliche (Padua, Meietti), ${ }^{8}$ que pretende ser una condena del nuevo "mostruo", nacido de espaldas a los rectos principios aristotélicos. Nótese que Il pastor fido todavía no ha sido publicado, pero ya corría de mano en mano desde casi una década antes. La respuesta de Giambattista Guarini se produce dos años más tarde, cuando publica un libro apologético titulado Il Verato ovvero difesa di quanto ha scritto messer Giason Denores contro le tragicommedie et le pastorali in un suo discorso di poesia (Ferrara, Vicenzo Galdura, 1588) y emprende una acalorada defensa de su tragicomedia, que considera atacada directamente en la obra de Denores, concretamente en la última parte, que ocupa apenas cinco folios de los cuarenta y tres que la componen. El erudito paduano responde a los nuevos argumentos con otro opúsculo, Apologia contra l'auttor del Verato (Padua, Meietti, 1590), que tendrá respuesta del poeta: Il Verato secondo ovvero replica dell'Attizzato Accademico ferrarese in difesa del Pastor fido contra la seconda scrittura di Messer Giason de Nores intitolata Apologia (Florencia, Filippo Giunti, 1593). Con la muerte de Denores la polémica concluye, pero Guarini sigue reelaborando su pensamiento crítico, que culmina con la publicación en 1601, junto a la versión definitiva de su tragicomedia, del Compendio della poesia tragicomica, tratto dai duo Verati, per opera dell'Autore del Pastor fido, colla giunta di molte cose spettanti all'arte (Venecia, Battista Ciotti), ${ }^{9}$ que podemos considerar una síntesis de la materia contenida en los dos escritos anteriores.

Las diferencias entre los dos Verato y el Compendio son considerables. En los primeros textos el tono agriamente polémico se hace evidente en las acusaciones directas que Guarini lanza contra Denores. El poeta lo tacha de perjuro por su declaración de que él no pretende atacar ninguna obra o autor en particular. Tenía motivos Guarini para darse por aludido, dado que su drama Il pastor fido es la primera obra en denominarse tragicomedia y su espíritu orgulloso no podía perdonar la manifiesta parcialidad de alguien hasta entonces considerado amigo

7. Sin menoscabo de la síntesis realizada por Wienberg (1961: II, 1074-1105).

8. Lo he consultado en Weinberg (1972: III, 373-326).

9. Citaré por la edición de Brognoligo (1914). 
y maestro. ${ }^{10}$ Las acusaciones alcanzan el ámbito de lo personal en la primera parte del Il Verato secondo, en la que Guarini llega a hacer insinuaciones sobre la falsa atribución de nobleza de Denores. ${ }^{11}$

La forma de los Veratos corresponde igualmente al modelo de las obras polémicas. Ambos están dedicados a los señores del poeta, que habían aplaudido ya en Ferrara los méritos de Il pastor fido, y en cuya protección se apoyan los argumentos de Guarini. Ambos, asimismo, se dirigen en segunda persona a Denores y reproducen, bien de forma integral, bien parafraseándolos, pasajes enteros de sus obras. El segundo Verato denuncia las modificaciones que Denores ha efectuado en el texto de su primer escrito para tratar de ocultar la evidencia de sus errores. Por otro lado, Guarini se oculta tras una impostura: en el primero de sus escritos es su amigo, el actor Verato, quien defiende al poeta; en el segundo, ya muerto el auténtico Verato, es otro amigo, con el nombre académico del $A t$ tizzato, el que lleva a cabo la impugnación de Denores. ${ }^{12}$

Todos estos elementos desaparecen en el Compendio, que es ya una auténtica poética, con la síntesis y la exposición sistemática de su pensamiento. Su propósito es la defensa de la novedad que Il pastor fido supone en el panorama de las letras italianas de su tiempo y la elaboración de una teoría crítica que dé carta de naturaleza a la tragicomedia como género moderno.

Esta polémica entre Guarini y Denores es el exponente más completo de lo que Weinberg (1961) llama la crítica práctica, es decir, la generada por la crítica más o menos inmediata de una obra concreta, que en Italia tuvo una incidencia mucho mayor. En relación con los géneros dramáticos, tenemos que tener en cuenta el capítulo XviII, sobre las polémicas que suscitó la Canace de Speroni y el conjunto de su obra trágica. La impresión se refuerza si tomamos también en consideración el número de obras dedicadas al género épico y a los poemas de Ariosto y Tasso en particular. Si hay algo parecido a esta crítica práctica en España son las polémicas en torno a las Soledades de Góngora. Pero también hubo crítica práctica en relación con el teatro. ${ }^{13}$ En estos textos la pura especulación está jaspeada de crítica literaria, que si bien no alcanzó la extensión y el rigor expositivo de la italiana, abordó con más o menos profundidad las obras de Lope de Rueda, Lope de Vega, Pérez de Montalbán, Calderón, Tirso, y lo más granado de la dramaturgia española del siglo xviI. Pero son juicios sobre el con-

10. Il Verato, fol. $55 \mathrm{v}$.

11. Il Verato secondo, p. 30.

12. Estas obras son interesantes, más allá de su contenido poético, por su propia constitución o formato, puesto que dicen mucho sobre los cauces retóricos que tomaron las discusiones entre los humanistas en los más variados campos — para esta cuestión, Sánchez Laílla (2000: 39-47)—, y facilitan la comprensión, por ejemplo, de la interesantísima pugna intelectual que dio origen a la Spongia y su Expostulatio en torno a la figura de Lope de Vega —véase González-Barrera (2011) y Conde Parrado (2012) -

13. Véase Alonso Veloso (2011: 374-377). 
junto de la obra de estos autores, y no sobre títulos concretos, sin duda porque la producción para la escena española es ya, desde comienzos de siglo, oceánica. Los juicios vertidos sobre obras o sobre dimensiones parciales de la producción de alguno de estos autores tienen el mismo valor que las modernas críticas literarias, como espejo en el que se reflejan las convenciones literarias más extendidas.

\section{Cascales y el Abad de Rute: la tragicomedia entre la condena aristotélica y la legitimación italiana}

1604, origen de la polémica en España en torno a la tragicomedia. Las Tablas poéticas y la Disdascalia multiplex, exponentes de actitudes opuestas

Vamos ya a resumir los distintos problemas planteados por la tragicomedia dentro de las discusiones teóricas que recorren el Renacimiento italiano, así como las soluciones, en tantos aspectos innovadoras, que Guarini propone. El Compendio, por su carácter expositivo más que argumentativo, nos servirá de guía en la mayor parte de los casos, pero completaré o aclararé el pensamiento del poeta con los dos Verato cuando así lo estime conveniente.

A manera de contraste llevaré a cabo un breve comentario de los pasajes en los que Cascales hace referencia a la tragicomedia y la despacha de manera muy sucinta, sin descartar las alusiones a otros autores que abordaron la cuestión de la tragicomedia desde presupuestos estrictamente aristotélicos. El motivo es doble: por un lado, este procedimiento nos ayudará a situar a estos autores en una tradición de fuentes y sistemas de pensamiento comunes; por otro lado, la polémica italiana nos aportará nuevos argumentos y puntos de reflexión de los que Cascales, como otros teóricos españoles, indudablemente tenía conocimiento, pero que, bien por veneración a la Poética de Aristóteles, o bien porque el propósito de su tratado era muy otro, no expuso de manera amplia y satisfactoria para el lector moderno. Las razones de Denores nos permitirán conocer mejor la postura de Cascales, y las soluciones de Guarini nos pondrán en la perspectiva histórica necesaria para entender el retraso de los comentaristas aristotélicos españoles con respecto a sus colegas italianos y a la propia realidad literaria que los rodeaba.

La elección de Cascales es también premeditada. Su situación en el tiempo lo convierte en el referente ideal para apreciar el desfase del pensamiento literario espańol respecto al italiano, cuya vanguardia está representada por Guarini, sin correr el peligro de adentrarnos demasiado en el siglo xvII. Las Tablas poéticas de Cascales, texto fundamental de las poéticas españolas, sorprenden por la parquedad del tratamiento que dispensan a la tragicomedia, máxime cuando tenemos en cuenta la fecha de su publicación. Claro que también hay que considerar que con probabilidad la obra se redactara hacia 1604, como coinciden en afirmar su editor, García Soriano (1952), y Vitse (1989). De esta forma se sitúa muy cerca en el tiempo del Cisne de Apolo de Carvallo (publicado en 1602, pero aprobado en 1600, lo que indica una redacción anterior) y de la Filosofía antigua poética de Ló- 
pez Pinciano (de 1596, pero de redacción probablemente anterior). De hecho, ni Pinciano ni Carvallo hacen mención alguna a la tragicomedia como género, sino que la nombran cuando mencionan el archiconocido Anfitrión de Plauto, donde se mezclaban dioses y hombres. Es cierto que el Cisne contiene lo que podríamos considerar la primera apología de la escena espańola de su tiempo, ${ }^{14}$ pero se encuentra en la parte en que trata de la comedia como género clásico y la referencia es demasiado vaga, relativa al artificio de la trama. En cuanto al Pinciano, los críticos parecen coincidir en que la Filosofía pudo estar redactada incluso en la década anterior - Newels (1974) señala que entre los años 1588 y 1593-, pues eso explicaría que alguien tan atento a la realidad literaria de su tiempo no hiciera mención alguna a Lope de Vega, a pesar de ser la figura principal del período en que la obra sale a la luz. Y como en el caso de Carvallo, no hay mención a la tragicomedia. Son los años anteriores a la difusión efectiva de Guarini en España y, en consecuencia, son indiferentes a nuestro análisis comparativo.

Está claro, pues, que la tragicomedia, vinculada o no a la explicación del teatro español contemporáneo, no es objeto de especulación teórica hasta el primer lustro del siglo XVII, justo cuando se difunden en España las fábulas pastorales de Tasso y Guarini; y no en vano el primer documento de teoría literaria que lo trata es el opúsculo del Abad de Rute, titulado "Comoediae ac Tragoediae differentiam aliam esse ab ea quae vulgo creditur", incluido en su Didascalia multiplex (Lyon, H. Cardon, 1615; es su cap. xxi) y redactado entre finales del siglo xvi y 1604, que es el primero también que habla de Il pastor fido y de los argumentos empleados por Guarini para su defensa. ${ }^{15} \mathrm{La}$ falta de referencias a autores españoles y el espacio concedido, por el contrario, a las polémicas italianas, hacen suponer que la redacción se produjo poco después de su regreso de Italia, donde había residido al servicio de su pariente y protector, el duque de Sessa. Newels (1974) pensó que el Abad de Rute se propuso contradecir las ideas sobre el drama expuestas en las Tablas poéticas, todavía inéditas, con lo que tendríamos el origen de una polémica a pequeña escala que no llegó a producirse. En todo caso, 1604 sería la fecha de origen de la discusión en torno al nuevo género en Espańa y no es casualidad tampoco que la más que probable fecha de composición del Arte nuevo de Lope sea más cercana en el tiempo a esta que a la de su publicación en 1609 (José Prades 1971).

En las Tablas, Cascales muestra su rechazo ante lo que los enemigos acérrimos del nuevo género dieron en llamar «monstruo» literario. ${ }^{16}$ La condena, sin embargo, no fue absoluta, hecho que podemos comprobar si recurrimos a un careo

14. Carvallo, Cisne de Apolo, p. 520: «LECT.-Si comprehender quisiésemos todo lo que a la comedia pertenece, a su traza y orden, mucho habría que decir y sería nunca acabar el querer decir los subtiles artificios y admirables trazas de las comedias que en nuestra lengua se usan, especialmente las que en nuestro tiempo hacen con tan divina traza enriqueciéndolas de todos los géneros de flores que en la poesía se pueden imaginar».

15. Véase Albalá Pelegrín (2013: 11-13), y el reciente estudio de Elvira (2018).

16. Véase Ferri Coll (2009). 
con otros escritos del autor. En una de sus Cartas filológicas, "Al Apolo de España» (II, 3), el rechazo de la comedia como fuente de perversión moral va unido a una alabanza de los ingenios españoles que medían sus armas en la escena. También en las Tablas poéticas se refiere a los autores contemporáneos en estos términos: ${ }^{17}$

Y es lástima que por falta del arte sea fruto perdido el de su fecundíssimo ingenio. (p. 23)

Cascales, convencido de que la falta de acomodación a las reglas aristotélicas se debe a la ignorancia que se tiene de estas, se propone remediar el problema y enseñar a los autores, con la ayuda, básicamente, de la poética aristotélica. ${ }^{18}$ Los pasajes relativos a la tragicomedia en las Tablas poéticas son los siguientes:

Castalio. - [...] De otro modo es doble también la fábula quando en ella ay personas ilustres y humildes, como en el Amphitrión de Plauto. Y a ésta llaman algunos tragicomedia, pero falsamente; porque la poesía scénica no abraça más que a la tragedia y comedia. Y si la fábula tiene materia trágica, acabando en felicidad, será tragedia doble; y si tiene materia cómica con personas graves y humildes, será comedia doble; y desta manera es el Amphitrión de Plauto. (p. 193)

Pierio.- [...] ¿ ¿No será doble también si la actión en parte fuere trágica y en parte cómica, como si en ella uviesse desgracias y acabasse en felicidad, y a esta tal la llamaríamos tragicomedia?

Castalio.- Si otra vez tomáis en la boca este nombre, me enojaré mucho. Digo que no ay en el mundo tragicomedia, y si el Amphitrión de Plauto se a intitulado assí, creed que es título impuesto inconsideradamente. ¿¿Vos no sabéis que son contrarios los fines de la tragedia y de la comedia? El trágico mueve a terror y misericordia; el cómico mueve a risa. [...] ¡Desterrad, desterrad de vuestro pensamiento la monstruosa tragicomedia, que es impossible en ley del arte averla! Bien os concederé yo que casi quantas se representan en esso teatros son dessa manera, mas no me negaréis vos que son hechas contra razón, contra naturaleza y contra arte. (p. 213)

\section{Prodesse / delectare: la cuestión de la utilidad moral}

\section{La controversia ética sobre el género dramático. Los silencios de Aristóteles. La autonomía de la creación poética. El placer de la imitación}

La polémica entre Denores y Guarini sacó a la luz algunos problemas que no hallamos sino implícitamente en la obra de Cascales, pero que nos pueden ayudar, precisamente, a comprender los límites de nuestro autor. Uno de los principales argumentos de Denores contra la tragicomedia es que la Poética se compone solamente de las partes dedicadas a la tragedia, la comedia y el poema heroico, y nada

17. Cito siempre por la ed. de Brancaforte (1975).

18. Brancaforte (1975: $\mathrm{x}$ ) señala convenientemente la importancia que la obra de Horacio tiene también en la Cascales. Cito por su edición. 
se dice en ella sobre el nuevo género. Guarini opondrá a estas razones un sinfín de pruebas que invalidan la idea de su contrincante, empezando por el hecho de que la Poética es una obra que ha llegado a nosotros incompleta, y muy bien podrían haberse perdido referencias a otros géneros considerados fundamentales en el origen y desarrollo de la tragicomedia. El poeta le recuerda que Aristóteles trata también de otros géneros, como la ditirámbica en la parte dedicada a la imitación y la diferencia entre las personas de las distintas manifestaciones literarias. ${ }^{19}$ Por otro lado, en la Poética falta la parte relativa a la comedia, que había sido anunciada al principio de la obra. En última instancia, Guarini recuerda que existen efectivamente otros géneros, reconocidos como tales de forma unánime, de los que nada o casi nada nos dice Aristóteles, como pueden ser las odas, las elegías o los epigramas. ${ }^{20}$

Que la Poética era un texto mutilado era algo ya generalmente admitido como verdad indiscutible en los años en que Cascales redacta su tratado, razón por la que probablemente obvia, en su condena de la tragicomedia, la argumentación de Denores, que pudo considerar poco concluyente. Es significativo también que en el Compendio de 1601 Guarini suprima esta argumentación, que había ocupado un espacio respetable en el primer Verato.

Para Denores, el filósofo griego excluye estas partes porque en nada favorecen el fin ético y político que ha de tener toda obra poética. No podemos olvidar que Denores es el principal representante de este principio de utilidad social y moral de la poesía:

[...] egli, como filosofo morale e civile, non si curò di favellar di ogni maniera di poesia che non ricevea le sue regole et $\mathrm{i}$ suoi principii dalla filosofia morale e civile e da' governatori e legislatori delle republiche a beneficio commune, ma solamente di quelle che, ricevendoli o non ricevendoli, poteano generar o buoni o cattivi costumi negli animi de' cittadini in universale. (p. 413)

No era el único. Numerosos autores hacían de la poética una parte de la filosofía moral, que apuntaba bien a servir a las necesidades políticas del Estado, bien a mejorar el carácter y la condición moral del ciudadano. Esta actitud, que procede de una larga tradición medieval con raíces clásicas, se refuerza en esta época con la relectura de la República de Platón y, más tarde, de ciertos pasajes de la Política de Aristóteles. Ahora bien, este principio se aleja de la argumentación estética y se desliza con claridad hacia lo que Vitse (1988) denomina la "controversia ética» en torno a la tragicomedia. No vamos a entrar en este aspecto, que nos llevaría muy

19. Il Verato, fol. $3 \mathrm{v}$.

20. Il Verato, fol. 7r-v. La lírica no entra en la poética hasta Minturno (L'arte poetica, Venecia, Valvassore, 1564), que la justifica teóricamente, lo que supone el fin de la división genérica bipartita, en género narrativo y género dramático, sostenida por las tradiciones platónica y aristotélica. Aristóteles se había referido a estos géneros de forma tangencial por no corresponder a la clasificación genérica basada en la mímesis, directa, indirecta o mixta. 
lejos, pero sí que pueden resultar ilustrativos algunos ejemplos que demuestran la vitalidad de este planteamiento. Véase, verbigracia, este pasaje, correspondiente a un prólogo de Quevedo, animal político donde los haya, a la Comedia Eufrosina del portugués Jorge Ferreira y Vasconcellos (Madrid, Imprenta del Reino, 1631): ${ }^{21}$

Mañosamente debajo del nombre de comedia enseña a vivir bien, moral y políticamente, acreditando las virtudes y disfamando los vicios con tanto deleite como utilidad, entreteniendo igualmente al que reprehende y al que alienta: extraña habilidad de pluma, que sabe sin escándalo ser apacible, y provechosa condición, que deben tener estas composiciones.

O el siguiente, del anónimo Discurso apologético en aprobación de la comedia de 1649, que no es más que una refundición de la epístola «Al Apolo de España» de Cascales, pero donde la perspectiva preferentemente filológica ha sido sustituida por otra decididamente colectiva y política: ${ }^{22}$

Pero aora, que con tanto decoro se representa; aora que está el teatro reducido á una escuela, donde va cada uno á ver su natural ó su oficio ó su ocupación, imitada tan vivamente de la agudeza del poeta, del modo que la deve seguir y no del modo que la obra para que aprenda la perfección de su estado, viendo en lo bien obrado lo que le falta para conseguirla, preciso es el sentimiento y grande la razón que tiene para sentir todo el pueblo verse privado de un acto de tanto deleite; con tanto provecho en el sentir de todos: pues los más apartados deste parecer, si no le conceden utilidad, le niegan, á lo menos, el daño.

Es el anuncio de la hipertrofia que las funciones políticas expresas sufrirán, por ejemplo, en el teatro áulico de Bances Candamo, bien estudiado por Ignacio Arellano (1988), y que anticipan las preocupaciones reformistas de los ilustrados.

Para justificar la ausencia de la tragicomedia en la obra del estagirita, Guarini, por su parte, encuentra una razón más evidente: Aristóteles no habló de la tragicomedia porque era un género desconocido en su época. En este aspecto podemos observar claramente la nueva actitud crítica que representa Guarini: el que no se halle bajo la autoridad del filósofo no impide que un género alcance el reconocimiento que merecen las auténticas obras de arte. El poeta recurre abundantemente a otro argumento de peso: de aplicar con rigidez las ideas de Aristóteles tendríamos que renunciar a obras como la Commedia dantesca ${ }^{23}$ o el Orlando furioso de Ariosto, que, a pesar de no responder a las exigencias de la Poética, son reconocidas como auténticos clásicos de las letras italianas. ${ }^{24}$

21. Tomo el pasaje de Porqueras Mayo (1968: 150).

22. Cito por Sánchez Escribano y Porqueras Mayo (1972: 237).

23. Il Verato, fol. $12 \mathrm{v}$.

24. Estos clásicos modernos de las letras italianas tuvieron que librar, en efecto, una dura batalla contra los preceptistas rígidamente aristotélicos. Para las polémicas que envolvieron la valoración de 
El criterio interpretativo del poeta italiano es claro: Aristóteles no pretende dar preceptos sobre los géneros, sino que, con su descripción de cada uno de ellos, intenta encontrar, por vía de inducción, los principios universales de la poesía. La tragicomedia, como las obras de Dante y Ariosto, obedece a las reglas universales de la poesía y, por tanto, merece un lugar en el Parnaso.

El punto de partida de Guarini en su consideración de la poética en general es el rechazo absoluto de la finalidad moral de la poesía. Esta no puede ser subalterna de la filosofía moral o civil, como afirma Denores, y para demostrarlo desarrolla distintos argumentos. En primer lugar, el fin de la filosofía moral es distinto del fin de la poesía. El poeta no tiene más misión que imitar, e imitar cualquier cosa, sea buena o mala. Es cierto que la tragedia imita en concreto las acciones de los hombres y su posible bondad o maldad, pero el arte de imitar se ocupa solo de las imágenes y no de la esencia de las cosas. En segundo lugar, la diferencia se halla en el objeto. La filosofía moral tiene como objeto la felicidad de los hombres; la poesía no tiene más objeto que la fábula. Cierto que también la poesía produce la felicidad, pero se trata de una felicidad diversa. La de la moral es una felicidad que procede de la sustancia, mientras que la de la poesía es una felicidad procurada por la representación de la sustancia a través de la palabra:

Non è dunque da maravigliarsi se l'imitazione diletta tanto, poiché per ella l'uomo impara di sapere, che è il primo desiderio e’l piú caro diletto e'l piú proprio dell'umana natura. [...] Or la poetica, fra tutte quelle arti che nell'imitazione spendono il lor talento, riesce maravigliosa, non solo perché imiti gli atti umani, nella quale opera non è sola, ma perciocché imita colla favella, nella quale è unica imitatrice [...] (Compendio, p. 221)

La moral considera la felicidad para conseguirla y la infelicidad para evitarla, y la poética considera ambas para imitarlas, porque ambas son objeto de su arte:

[...] però giova il Poeta quando diletta $\&$ se diletta è Poeta, ma se giova senza diletto è più tosto filosofo o altro artefice. Et se sparge i suoi poemi di buoni costumi, il fa solo per dilettare; conciosiache l'imitazione di tutte le cose eziandio horribili, $\&$ mostruose non che delle buone, \& tanto amiche della nature, quanto sono i costumi ci recano gran piacere. (Il Verato, fol. 11v)

Los mismos argumentos son válidos para la comedia y el poema heroico, así como para el resto de las artes, que no reciben sus principios de la política, sino cada una de lo que le es consustancial: la música, por ejemplo, toma sus principios exclusivamente de la aritmética (no en vano había formado parte del Quadrivium).

En ninguna parte de la Poética se habla de principios morales. Tampoco se ve en ninguna parte que la poesía deba estar sometida a la política. Denores, según

La divina comedia véase Weinberg (1961: II, caps. XVI y xvII). Para las controversias sobre el poema épico de Ariosto, véase también Weinberg (1961: II, caps. XIX y xx). 
Guarini, confunde la Poética con la Política de Aristóteles. ${ }^{25}$ El poeta, en las partes formales de su obra, no depende de la política y jamás se ha oído que una ley haya regulado la poesía. Del mismo modo la poesía no ha sido instituida para provocar en los ciudadanos el amor a la república. Este fin que señala Denores resulta repugnante a la recta doctrina de Aristóteles. De todas formas, el reproche que el poeta lanza a su contrincante podría aplicarse a muchos otros pensadores, porque en este momento se entendía la obra de Aristóteles como un todo orgánico, lo que permitía recurrir a otras obras del filósofo para explicar pasajes de una obra determinada, como ocurría con la Retórica para completar los problemas de la elocución en la Poética.

$\mathrm{Si}$, a pesar de ello, tomamos en consideración los principios morales que reclama Denores, nada nos obliga a pensar que la tragicomedia, como otros muchos géneros, haya sido excluida de la Poética por este motivo. Ni la ditirámbica, que trata de los dioses, ni los himnos y odas de Píndaro, Horacio o el mismísimo rey David pueden ser sospechosos de atentar contra el bien de la república. ${ }^{26} \mathrm{De}$ igual forma, el sometimiento estricto a los principios de la moralidad podría dañar la necesaria verosimilitud, peligro del que advierte el propio Aristóteles: nada puede hacernos creer la existencia en la tragedia de personajes perfectísimos. ${ }^{27}$ En definitiva, Guarini está apelando con estas consideraciones a una poética fundada en la razón y no en motivos ajenos a la auténtica creación literaria.

En las Tablas poéticas no hacen acto de presencia las razones sobre la utilidad política de los géneros, pero Cascales muestra una constante preocupación por la moralidad de la obra poética; inquietud que, en literatura, es el resultado del programa de adoctrinamiento moral que el concilio tridentino promovió en todos los campos de la vida social y política del cambio de siglo.

Más evidente, sin embargo, que en las Tablas, es la reflexión sobre la moralidad de las comedias que encontramos en la epístola II, 3 de sus Cartas filológicas, cuyo asunto principal es la licitud de representar malas acciones. Las Cartas filológicas aparecieron en 1634, pero el privilegio de la obra es de 1627, lo que adelanta bastantes años las ideas contenidas en esta epístola. Estas se hallan justificadas por la finalidad docente de la poesía, ya que, de la misma manera que el buen ejemplo de las personas virtuosas incita a los actos de virtud, el fin desgraciado de los personajes moralmente rechazables nos aparta del vicio en que estos cayeron. En último extremo, pero solo en último extremo, nos queda el placer que produce la mera imitación:28

Últimamente, digo que no solo la comedia enseña, pero que también deleita, ya con la imitación de las acciones y costumbres buenas, como hemos visto, y con las malas y con las lastimosas.

25. Il Verato, fols. 5v-6r.

26. Il Verato, fol. $7 \mathrm{r}$.

27. Il Verato, fol. 6v.

28. Cito por la edición de García Soriano (1953: 68). 
Es un atisbo, pequeñísimo pero indicativo, de una libertad creativa de la que Tasso ya se había hecho adalid en Italia casi dos décadas antes, diciendo de su Aminta, v. 681, que «'sei piace, ei lice» (es decir, «si gusta, es lícito») y Lope de Vega con su Arte nuevo, pocos ańos más tarde, acogiéndose con mayor o menor convencimiento a los gustos del público.

\section{La tragicomedia como género mixto: el problema de la unidad}

\section{La imitación verosimil y la "terza natura». La armonía de los contrarios y el principio de la atemperación}

Hemos visto cómo la imitación es considerada la finalidad exclusiva de la poesía y en la imitación, precisamente, se halla justificada la tragicomedia como género mixto. ${ }^{29}$ Sobre la mixtura pesaba la condena de Horacio, cuando en su Ars poetica, 1-5, nos dibuja un ser con cabeza humana, cuello equino, plumas y cola de pez, que representa la fábula carente de unidad. Esta representación de algo que es todo y nada al mismo tiempo dará pie a toda una serie de imágenes que los defensores del nuevo género van a publicitar con afán reivindicativo, como la «vil quimera» y ese «minotauro de Pasife» a los que hace referencia Lope de Vega (Arte nuevo, vv. 150 y 176), ${ }^{30}$ y que se unieron a otras metaforizaciones de la mixtura, como la salsa agridulce con que Pinciano aludió a la presencia de episodios cómicos en la tragedia clásica, la abeja que, recolectando el néctar de flor en flor, significaba desde antaño el principio de la imitación compuesta, o el emblema — que es además una mezcla de lenguajes, verbal y pictórico- de Heráclito y Demócrito que dibuja la realidad de una existencia donde lágrimas y risas van de la mano (Egido 1998).

No obstante, hay que decir que esta acusación de monstruosidad desborda el género dramático y afecta a otras manifestaciones literarias. Pensemos por ejemplo en la severidad con que Pedro de Valencia condena en las Soledades la mezcla de lo lírico y lo épico, de lo grave y lo burlesco; o en sentido contrario, recordemos que los defensores de Góngora llegarán a comparar el deleite que produce su poema con el gusto generado por la comedia nueva.

Pero lo mixto no pertenece solo al ámbito del artificio, como las pinturas de Arcimboldo, sino que es una realidad natural, y los autores de la época no tenían que recurrir al hermafrodita que cita Cascales (Tablas poéticas, p. 194), o al catálogo de monstruosidades que recogía, por ejemplo, Torquemada en su Jardin de flores curiosas, sino que bastaba mirar alrededor, como hace Guarini. Dice el poeta italiano que no se puede apelar al carácter «mostruoso» de Il pastor fido y las demás obras de sus características, puesto que la misma naturaleza

29. Para la cuestión de la mixtura genérica, véase Arellano (2011).

30. Véase Grünnagel (2010). 
nos da ejemplos de extrańas mezclas. Y recurre a la autoridad de Aristóteles en su libro sobre la Generación de los animales, donde se da cuenta de una «tercera naturaleza» que surge de la unión de animales dispares como el zorro y el perro o el caballo y el asno. ${ }^{31}$

Esta tercera naturaleza, que tanto trabajó literariamente Cervantes en $\mathrm{La}$ Galatea - sobre todo en la parte del libro que se desarrolla en el Valle de los Cipreses-, o terza natura, como llamaban los italianos al sometimiento de la naturaleza por el arte y que sirvió de argumentación especulativa para la riquísima tradición del jardín italiano, resultaba familiar a todo un público selecto, acostumbrado a conceptos refinados como el del ingenio que hace orden y arquitectura de las mismas selvas o como el de la natura artifex que vuelve por sus fueros e integra la obra del hombre para crear nuevos espacios de maravilla y deleite; conceptos que circularon en la riquísima producción de poemas sobre jardines y ruinas, pero que hallaron también acomodo y, no por casualidad, en la novela pastoril. De la misma forma que animales de distinta especie se unen, también las distintas artes admiten este tipo de ayuntamientos: el propio jardín, pero también la pintura, no es sino una mezcla de colores distintos. Ricardo del Turia dice en su Apologético de las comedias españolas ${ }^{32}$ que en la comedia cabe todo, como en una tabla o en un lienzo, idea que se apoyaba en el tópico horaciano del ut pictura poesis, relativo a la esencia de la imitación. Y a la pintura se suma la música, que es un conjunto de elementos sometidos a la armonía por el arte de su autor:

Concedasi anche questo, e parliamo della pittura, ch'è della poesia cugina carnale: non fa ella, senza l'opera d'altro mezzo, diverse mescolanza de' suoi colori? Il medesimo si dirà della musica, ad un parto medesimo nata con la poesia $[\ldots]$ truovisi finalmente mistura tanto simile alla poetica che differenza alcuna tra lor non sia, se non quella che si conosce tra il vero e'l finto. La quale è tanto propria del nostro caso, che la figura è quasi la stessa cosa col figurato, essendo la poesia niente altro chél verisimile imitato. (Compendio, p. 228)

Ya que la poesía es «lo verosímil imitado», la tragicomedia no atenta contra la verosimilitud en su índole mixta, al comportarse como otros elementos de la naturaleza. No podemos aquí obviar la cercanía de estos argumentos con la teoría del injerto que podemos leer en los Cigarrales de Toledo de Tirso de Molina. Forma parte de un pasaje de esta miscelánea en el que Tirso de Molina recoge los principales argumentos expuestos por Lope de Vega en el Arte nuevo, pero

31. Compendio, p. 227.

32. Recogido en Norte de la poesía española. Ilustrado del sol de doce comedias (que forman segunda parte) de laureados poetas valencianos, y de doce escogidas loas, y otras rimas a variados sujetos de Aurelio Mey, Valencia, Felipe Mey, 1616. Véase el trabajo de Elvira (2015), que pone en relación este texto de Turia con los argumentos de Guarini. 
que ofrece algo más que una mera sumisión a los preceptos del Fénix (Maurel 1971: 17-30). Y es que Tirso vio justificado en el principio de libertad creadora, establecido por el mismo Lope, su propósito de llevar a cabo una creación original. Si él compartía la fórmula lopesca es porque esta le ofrecía en su misma naturaleza la posibilidad de nuevas combinaciones, que queda expresada en Los Cigarrales mediante la comparación del «injerto» y el desarrollo de una peculiar teoría de la evolución: ${ }^{33}$

Pues si «en lo artificial», cuyo ser consiste sólo en la mudable imposición de los hombres, puede el uso mudar los trages y oficios hasta la sustancia, y «en lo natural» se produzen, por medio de los ingertos, cada día diferentes frutos, ¿qué mucho que la Comedia, á imitación de entrambas cosas, varíe las leyes de sus antepassados y ingiera industriosamente lo trágico con lo cómico, sacando una mezcla apacible destos dos encontrados poemas, y que, participando de entrambos, introduzga ya personas graves como la una y ya jocosas y ridículas como la otra?

A partir de la aceptación de la imitación verosímil, Tirso defiende el derecho de la comedia española a crear una nueva especie, la tragicomedia, de la misma forma que, en la naturaleza, de dos especies distintas puede nacer una tercera, ya sea de manera natural o por medios artificiales, como el injerto.

Solo seis años más tarde, Feliciana Enríquez, curiosa dramaturga y notable reivindicadora de los méritos de las mujeres en la república de las letras, en el prólogo "A los lectores» de su Tragicomedia de los jardines y campos sabeos (Lisboa, Pedro Craesbeeck, 1627), justifica su tragicomedia, al igual que Tirso, por la existencia de cosas mixtas en la naturaleza:

Y los acutísimos y prudentísimos iureconsultos, que tuvieron tan buen voto en toda filosofía, admitieron acciones mistas, por participar de reales, y personales; como la arte y naturaleza también han admitido los mistos y compuestos. (fol. 48r)

Queda claro que para la autora el género de la tragicomedia ya ha adquirido carta de naturaleza, e incluso considera que, una vez admitida su esencia, se ha de someter a las reglas, y ella misma se jacta de que su tragicomedia respeta escrupulosamente las unidades de tiempo y espacio.

De esto que venimos diciendo se deduce que el problema del nuevo género es, básicamente, un problema de unidad. Para Denores es imposible reducir a un único texto dos composiciones de naturaleza tan diversa e incluso contraria. Este es el mismo punto en el que encontramos a Cascales en las Tablas poéticas. Denores, sin embargo, ejercita una reflexión dialéctica entre los dos géneros, ${ }^{34}$ algo a lo que Cascales es completamente ajeno. El mismo tipo de reflexión lleva a cabo Guarini para rebatir uno por uno los argumentos del paduano.

33. Tomo el texto de Muriel (1971: 127).

34. Discorso, pp. 413-414. 
En primer lugar, aclara que la tragicomedia no es la mera suma de los elementos de la tragedia y de la comedia, sino un tercer género, perfecto en sí mismo, que contiene los elementos de la tragedia y los de la comedia que verosímilmente pueden estar juntos. El término exacto para definirlo es el de "género mixto", y no el de género compuesto o complejo, usado por Denores, que da precisamente la idea que Guarini quiere evitar por todos los medios:

[...] hassi a considerare che la tragicommedia non è composta di due favole intere, l'una delle quali sia perfetta tragedia, e perfetta commedia l'altra, congiunte insieme di modo che ambedue si possano disunire senza che l'una guasti i fatti dell'altra o ciascuna i suoi propri. (Compendio, p. 224)

\section{La misma preocupación muestra Ricardo del Turia en su Apologético: ${ }^{35}$}

Doctrina es del Filósofo en el primero De Generatione, muy vulgar, donde muestra la diferencia que hay entre lo mixto y lo compuesto. Porque en lo mixto las partes pierden su forma y hacen una tercer materia muy diferente, y en lo compuesto cada parte se conserva ella misma como antes era, sin alterarse ni mudarse, antes bien se compone junta, y lo que nace de esta composición no es un tercero alterado debajo de diferente forma, pero son dos cuerpos que trocándose no se compadecen entre sí, y se quedan los mismos que eran antes, así en acto como en potencia.

La mezcla es posible desde el momento en que ambos géneros son formas dramáticas. El resultado, por consiguiente, es también una forma dramática, cuyos elementos esenciales son la representación, la armonía, el tiempo limitado, la fábula dramática, la verosimilitud, el reconocimiento o anagnórisis y la peripecia, ${ }^{36}$ todos ellos extraídos directamente de la Poética aristotélica. Veamos ahora los elementos en los que tragedia y comedia pueden hallar puntos en común.

Según la Poética, a la tragedia corresponden los personajes grandes, mientras que en la comedia encontramos a las personas privadas y humildes. Sin embargo, no es descabellado mezclar en una misma fábula los dos tipos de personajes. De ello nos dan ejemplo autores clásicos, desde Sófocles, que introduce en sus tragedias siervos y soldados. De igual manera, Aristófanes presenta en sus comedias a ciudadanos y villanos. Pero no basta solo la autoridad de los antiguos. La tragicomedia, como imitación que es, reproduce la misma mezcla de individuos de toda calidad que se encuentra en la república. Aristóteles habla en su Política de la «república mixta», que contempla al mismo tiempo la democracia y la oligarquía. Y si la política admite las naturalezas mixtas, también puede hacerlo la poesía. No hace Guarini sino usar pro domo sua un argumento del contrario, al que antes había reprochado confundir la Poética de Aristóteles con su República.

35. El pasaje se encuentra en el f. A4r.

36. Compendio, p. 225. 
Ma, se in una sola comunanza sarà il dimocratico e l'oligarchico, seguirá che nello stesso soggetto possano esser due forme di diversa spezie e di natura contrarie. [...] Dice dunque Aristotile che nella repubblica mista son ambedue le forme, ma si ben temperate, che la stessa e sola repubblica può parer l'una e l'altra delle due miste, e tuttavia non è né l'una né l'altra intera. [...] Il medesimo si dé' dire della tragicommedia, nella quale il tragico e'l comico, non come intere forme, ma come qualità del poema tragico e comico, si ritruova. (Compendio, pp. 229-230)

Del mismo modo, son propias de la tragedia las acciones graves y de la comedia, las acciones privadas. Las primeras son causa del terror y la piedad; las segundas provocan risa. Y de nuevo recurre Guarini a las autoridades: Plauto, en su Anfitrión, presenta junto a reyes y dioses las burlas de Mercurio. ${ }^{37}$ Cascales aduce los mismos principios, que no son otros que los señalados por el filósofo:

Y no basta que la materia sea imitable: obligado estás a elegirla según la calidad del poema. La materia de la comedia no es buena para la tragedia. Y al contrario, el cómico tiene por fin la risa, el trágico tiene por fin la misericordia y el miedo: elegirá materia apta para provocar a misericordia y miedo. (Tablas poéticas, p. 32)

Tan solo hay un punto en el que ambos géneros no pueden ir de acuerdo. Si la alegría puede mezclarse convenientemente con la piedad —la misericordia, dice Cascales_- es completamente contraria al terror, que pertenece exclusivamente a la tragedia y es provocado por medio de escenas graves y funestas:

Può dunque stare non dico l'allegrezza e'l dolore, ma la pietà col riso in una favola stessa. E cosí tutta la somma di questa contraddizione si verrebbe a ridurre ad una sola differenza, cioè il terribile, la quale non può mai stare se non in favola tragica, né seco mai alcuna comica mescolarsi, perciocché il terrore mai non s'induce se non per mezzo delle gravi e funeste rappresentazioni; e dove questo si truova, non v'ha luogo riso né scherzo. (Compendio, p. 227)

Estas observaciones ponen de manifiesto la posibilidad de una obra mixta. Para ejemplificar el procedimiento que ha de seguir el autor, Guarini recurre al símil del antídoto que, purgando del veneno las partes nocivas y dejando las salutíferas, es capaz de producir un efecto positivo, por un proceso de compensación que remite en última instancia a la teoría de los humores. ${ }^{38}$ Así es capaz de aislar los elementos aprovechables y descartables de cada uno de los géneros para lograr el género mixto:

Cosí fa chi compone tragicommedia, perciocché dall'una prende le persone grandi e non l'azione; la favola verisimile, ma non vera; gli affetti mossi, ma rintuzzati; il diletto, non la mestizia; il pericolo, non la morte; dall'altra il riso non dissoluto,

37. Compendio, p. 226.

38. Compendio, p. 231. 
le piacevolezze modeste, il nodo finto, il rivolgimento felice, e sopratutto l'ordine comico, del quale a suo luogo ragioneremo. (Compendio, p. 231)

El principio que rige estas consideraciones son las nociones aristotélicas de potencia y acto:

[...] il concorso delle parti tragiche e comiche circoncise faranno quella potenza molto debole e molto rimota da potersi produrre in atto. (Compendio, p. 231)

La tragedia entera es la tragedia misma en acto; cada una de sus partes, sin embargo, es individualmente tragedia solo en potencia. Lo mismo ocurre con la comedia:

[...] la forma della tragedia in ciascuna parte di lei non è se non in potenza, né si riduce all'atto, se non concorrono l'altre parti, e perché il fine della natura, nelle rimescolanze de' corpi che i greci chiamano omogenei, è di produrre in atto una sola cosa di quelle due che concorrono. (Compendio, p. 232)

Por tanto, para poder formar una tragicomedia, se debe operar sobre cada una de las partes aisladamente. De la misma manera que la naturaleza atempera sus cuatro elementos para producir diversos compuestos, el artista modifica las partes destinadas a formar el género mixto. Esta operación admite diversos grados, y una obra puede tener más de lo cómico que de lo trágico, como es el caso del Anfitrión de Plauto; o viceversa, como podemos comprobar en el Cíclope de Eurípides. ${ }^{39}$

Estas partes susceptibles de modificación ya eran bien conocidas por los clásicos. Es muy interesante a este propósito la obra de Seidensticker (1982) dedicada a la presencia de elementos cómicos en las tragedias griegas. Las páginas de este libro — titulado significativamente Palintonos Harmonia, es decir, la armonía de los contrarios- son una magnífica y clara síntesis de los elementos susceptibles de ser subvertidos en cada uno de los géneros básicos - tragedia y comedia-, para dar lugar al género mixto que es la tragicomedia. En primer lugar, se podían mezclar personajes de distinta cualidad moral o de distinta posición social. También los argumentos, de distinta naturaleza —cómicos o trágicos, relevantes o triviales-, u organizados de manera diferente en función de un final distinto al que en principio debiera corresponderles. El estilo puede sufrir combinaciones dentro de una obra, plenamente diferenciado por escenas o por personajes, pero también se pueden tratar asuntos trágicos en estilo de comedia y viceversa, o bien se puede crear un estilo medio que evite los extremos. Este sistema de equilibrios puede darse igualmente con relación al efecto de la pieza. La alegría y el dolor, junto con la risa y el llanto que les sirven de expresión, obedecen a un intercambio de escenas cómicas y trágicas, dispuestas

39. Compendio, p. 247. 
unas detrás de otras, o al paso de una situación afortunada a una desgraciada, y en el sentido contrario.

Todo esto, como decimos, estaba ya en los griegos, pero también se descubre en esta época, a caballo entre los siglos XVI y XVII, la posibilidad de una síntesis de efectos mediante la armonización de elementos cómicos y trágicos amortiguados. Y no es otra la propuesta que podemos leer en las páginas de Guarini. De esta forma, los mismos elementos que en la Antigüedad servían para establecer fronteras infranqueables entre los géneros se convierten ahora en la esencia del «monstruo tragicómico».

\section{La catarsis tragicómica}

El problema de las finalidades opuestas. Fines arquitectónicos e instrumentales de los géneros clásicos. Los grados de la tragedia

El mayor obstáculo para la constitución de la tragicomedia es, no obstante, más allá de los rasgos opuestos uno a uno entre los dos géneros, la diferente finalidad de los géneros implicados. Guarini trata el problema distinguiendo en cada uno de ellos un doble fin: el instrumental, en razón del cual el poeta da forma a la obra con los elementos que tiene a mano; y el arquitectónico, por el cual es llevada a cabo la operación. Para ilustrarlo acude de nuevo a un símil, esta vez el del arquitecto que se propone la construcción de una casa. El fin instrumental es, precisamente, construir la casa con los materiales que tiene a su disposición. El segundo es construir la casa para que sea habitada. ${ }^{40}$

En la comedia el fin instrumental es el ya señalado por Aristóteles: imitar las acciones de los hombres privados que, con sus defectos, mueven a risa. El arquitectónico lo podemos conjeturar de las circunstancias anteriores: dado que el origen de la comedia está en las bacanales, en plena fiesta de embriaguez y lascivia, le parece a Guarini que ha de ser el de purgar los ánimos de las pasiones causadas por las tribulaciones, no solo privadas, sino también públicas. La comedia purga, en concreto, la melancolía, afecto nocivo que a menudo lleva al hombre a la locura o al suicidio. ${ }^{41}$

El fin instrumental de la tragedia consiste en la imitación de algún caso horrible o digno de piedad. El arquitectónico es la purgación del terror y de la piedad. Ambos afectos aparecen recogidos en la Poética de Aristóteles, y son los que Cascales, al igual que Denores, y la práctica totalidad de los comentaristas aristotélicos, exponen en sus tratados:

De manera que el poema no basta ser agradable, sino provechoso y moral, como quien es imitación de la vida, espejo de las costumbres, imagen de la verdad. ¿Quién

40. Il Verato, fol. 20r-v.

41. Compendio, p. 234. 
duda, sino que leyendo los hombres las obras de poesía, o hallándose en las representaciones tan allegadas a la verdad, se acostumbran a tener misericordia y miedo? De aquí procede que si les viene algún desastre humano, son ya menores el dolor y el espanto. Que es cosa llana y cierta que quien nunca a passado calamidad, si le sobreviene sin pensar y de improviso, no tiene paciencia para sufrirla. Y también ay muchos que sin razón se afligen y temen. Oyendo, pues, en los teatros y leyendo en los poemas cosas digníssimas de conmiseración, y que aun el muy sabio conviene que las tema, aprenden quál es de lo que emos de doler y emos de temer. (Tablas poéticas, pp. 38-39)

De los afectos purgados por la tragedia, Guarini no ve motivo para incluir entre ellos la piedad, entendida como compasión del mal ajeno, puesto que considera que el hombre no debe despojarse de este sentimiento, en cuanto que es bueno e intrínseco a la misma humanidad:

E'n veritá, che'l terrore s'abbia a purgare, come affetto disordinato che corrompe la virtú della fortezza, ha molto del ragionevole o, per dir meglio, del necessario. Ma spogliarsi della pietà, chi può farlo senza spogliarsi d'umanità? Per modo che la tragedia per questo solo meriterebbe d'essere, como fiero e scandaloso spettacolo, abborrita. (Compendio, p. 235)

Ahora bien, el dolor por el mal de los hombres puede tener dos fuentes. La compasión por los sufrimientos físicos es negativa cuando estos obedecen a un justo castigo o son efecto de la penitencia por un pecado. En estos casos el sufrimiento fortifica y purifica, como un médico que, para curar una llaga, primero ha de cauterizarla. En este sentido son admirables los ejemplos de Áyax, Edipo o Ifigenia. ${ }^{42}$

El terror, por el contrario, es un sentimiento desordenado que corrompe la fortaleza de los hombres, por lo que es razonable su purgación. Sin embargo, hay que distinguir también dos tipos de terror: el miedo a la muerte de los sentidos y el miedo a la muerte interior. El fin de la tragedia no es purgar el miedo a la muerte física, sino dar vigor al espíritu. Enseñando lo terrible que puede ser la muerte del alma del hombre, nos invita a no tener miedo de la muerte del cuerpo. Los ejemplos clásicos de héroes que no temen los tormentos físicos cuando es torturada el alma son muy ilustrativos: Edipo no se lamenta de la pérdida del reino o de sus ojos porque es devorado por el dolor del parricidio y el incesto cometidos; Ifigenia, para obrar bien, pone en peligro su propia vida. ${ }^{43}$

Nosotros, con respecto a estos argumentos, no podemos dejar de notar de qué modo Guarini es deudor en algunos aspectos de la misma concepción ética de la literatura que tanto ha denostado en Denores y que Cascales manifiesta en los pasajes arriba presentados. De hecho, la catarsis no fue nunca y de forma ex-

42. Compendio, pp. 240-241.

43. Compendio, pp. 238-239. 
clusiva un problema de índole estética, ${ }^{44}$ vinculado a la esencia misma del género trágico, sino que se enmarcó en una discusión más amplia sobre el par horaciano prodesse-delectare. Estoicismo, platonismo, aristotelismo y moral católica tuvieron un papel destacado en el desarrollo de un concepto de la catarsis en el que solo pareció imponerse de manera universal el llamado principio mitradático, según el cual la tragedia tenía la misión de proteger al público del mal, cualquiera que fuese la naturaleza de este, y que quiere hacer de la tragedia un ejercicio de familiarización con las emociones más fuertes, no muy lejano del postulado de la admiración barroca. En el fondo se trataba de salvar a la poesía del ostracismo al que la había enviado Platón dotándola de una utilidad para la república.

Guarini se muestra también contrario a Denores en el modo en que se ha de efectuar la purgación. Según el paduano —y así lo vemos también en Cascales—, el terror se elimina con la representación de escenas crueles a las cuales el espectador llega a acostumbrarse. Lo explica mejor mediante el ejemplo del soldado que, familiarizado con la presencia de cuerpos muertos en escena, supera la impresión que estos puedan producirle en el campo de batalla, y ello redunda en el fortalecimiento de su valor. Y aquí podríamos traer a colación la cuestión de la representación en escena de actos violentos, que, apoyada en el tema horaciano de la superioridad del efecto de la visión sobre el de otros sentidos, habría que relacionar con ese conjunto de obras trágicas que Hermenegildo (1985) dio en llamar la tragedia del horror. Su aceptación acarreaba reparos de orden moral, y tenía también implicaciones en el espinoso asunto de la verosimilitud imitativa, en el sentido de que no se podían representar de forma convincente ciertas atrocidades.

Guarini cree que esta argumentación es falsa. El contemplar a menudo la muerte no aumenta el valor de los hombres. El efecto es, precisamente, su opuesto. El espectador que se acostumbra al trato frecuente con la muerte se despoja de su humanidad, lo cual significa hacerse más cruel. Así nos lo enseña

44. De esta cuestión fundamental se produjeron multitud de ramificaciones en forma de problemas parciales: si el miedo y la compasión debían ser purgados o si solamente se debían purgar estos sentimientos y no otros — Guarini, por ejemplo, quiere someter la melancolía a la purificación dramática-; si las pasiones debían ser extinguidas o simplemente moderadas; si solo se debía purgar el miedo y no la compasión, que es una virtud cristiana; si estas pasiones eran buenas o malas en sí o según el objeto al que fuesen dirigidas; o si la purgación se podía aplicar también a la comedia. A estos se añaden otros problemas secundarios como la utilidad pública y política de la tragedia y la expulsión de los poetas de la república platónica. Para exponer estas ideas los tratadistas se sirvieron de identificaciones entre la acción catártica del drama y la teoría psicológica de los humores, la catarsis musical tratada por Aristóteles en su Política o la doctrina de la simpatía natural. Queda clara, pues, la complejidad del concepto y la multitud de factores y consideraciones teóricas que le afectan. El problema central de la catarsis ha ocupado la atención de numerosos estudiosos, en aspectos que van desde el desentrañamiento del auténtico sentido del término en el pasaje 49b27-28 de la Poética, para lo cual podemos leer a García Yebra (1974: 379-391 y 339-375), a los intentos de clasificar las distintas interpretaciones del término. Al mismo propósito obedece el trabajo de Kitto (1966). Para un panorama interpretativo del concepto desde las distintas corrientes críticas, son básicos los libros de Hathaway (1962) y Abdulla (1985). 
Aristóteles en su Moral. Por otro lado, es falso que la representación de escenas crueles fuese frecuente en las tragedias griegas. Al contrario de lo que señala Denores, son muy raras las muertes que se ven en escena o la presencia de cuerpos muertos en el escenario. Apenas puede citar el autor la Fénix de Eurípides. ${ }^{45}$

Otro problema que suscita la representación de escenas terribles es el suicidio de algunos personajes de la tragedia clásica, como Catón, Bruto o Lucrecia. Los autores no pretenden presentar el suicidio como una acción virtuosa, lo cual haría inaceptable su misma lectura para un cristiano, sino mostrar, volviendo a los argumentos anteriormente expuestos, que el dolor del alma puede ser tan grande que la muerte del cuerpo resulte insignificante. En todo caso, se puede representar el suicidio en escena porque el fin de la tragedia no es enseñar la virtud:

Che finalmente la tragedia è una favola e non ha per suo scopo d'insegnar la vertù, ma di purgare quelle due perturbazioni dell'animo, in quanto può una favola, che fanno ostacolo alla fortezza, che'n tutti gli atti umani è tanto nobile e necessaria vertú. (Compendio, p. 240)

En estas circunstancias, el poeta italiano distingue finalmente dos tipos de purgación distintos, o más bien, dos sentidos diversos de la palabra purgación. El primero de ellos es el de apagar los efectos del alma, erradicarlos por completo del corazón de los hombres del mismo modo que lo hacían los filósofos estoicos. El segundo, que es el sentido por el que aboga el poeta, es el de purificación. Para explicarlo recurre una vez más al símil tan querido del médico que, para curar la cólera, no elimina el humor, sino que lo reduce a la temperancia que puede producir la virtud. La catarsis consiste, por tanto, en la moderación de los sentimientos:

Non purga dunque il poema tragico gli affetti suoi alla stoica, spiantandogli totalmente da' nostri cuori, ma moderandoli e riducendogli a quella buona temperie, che può servire all'abito vertuoso. (Compendio, p. 237)

En todo caso, Guarini no escapa en esta, como en otras ocasiones, a lo que los estudiosos de este concepto denominan "punto de vista pedagógico» en la consideración de la catarsis aristotélica. ${ }^{46}$

Todas estas reflexiones están orientadas a la desarticulación de lo terrible y su necesaria purgación, objetivo en el que el mismo Guarini cifraba, como hemos visto, la principal dificultad para unir tragedia y comedia en un género mixto. Tras estas consideraciones podemos resolver el problema de la unión de los fines de la tragedia y la comedia. En primer lugar, es imposible unir los fines arquitectónicos, puesto que uno alegra y el otro entristece; uno relaja, y el otro conmueve los ánimos. Son, pues, fines contradictorios.

45. Compendio, p. 236.

46. Véase a este propósito el trabajo clásico de Russo (1950). 
El fin instrumental, sin embargo, puede ser mixto, ya que muchas partes de la tragedia, si eliminamos de ellas lo terrible, son capaces de producir, junto a las partes de la comedia, el placer de lo cómico. Si de una tragedia quitamos lo terrible y lo reducimos solamente al peligro de que algo terrible suceda, y añadimos además la risa, que suaviza la acción, tenemos el principio de la tragicomedia. Nos quedará el placer de la imitación, que será trágica solo en potencia y no en acto. ${ }^{47}$

La consideración de la tragedia y de lo tragicómico conlleva una serie de problemas secundarios que tienen también su importancia para explicar la naturaleza de la tragicomedia. Lo terrible no constituye tragedia de manera automática. La imitación de hechos horribles y miserables no es de por sí tragedia si simultáneamente no concurren los otros elementos que se hallan incluidos en la definición del género. De no ser así subsiste el placer que produce la imitación trágica, pero no se alcanza el fin catártico al que aspira:

Consiste dunque il diletto tragico nell'imitazione di fatti orribili e miserabili, la quale per se stessa, come dice Aristotile, è dilettevole. Ma non basta: bisogna che l'altre parte ancora sien tali, se si vuol bene conseguire il fin di purgare; altramente non si farà tragedia se non equivocamente, cioè fuori de' termini della definizione datale dal filosofo. (Compendio, p. 243)

Por otro lado, la tragedia admite grados. Es cierto que cuanto más terrible y más digna de compasión sea la fábula, más trágica será la obra. De la misma forma, la cualidad de trágico es alterable y se puede obtener obras más o menos trágicas según el contenido más o menos terrible de la fábula. El mismo Aristóteles reconoce la existencia de grados imperfectos de tragedia. Una tragedia es menos trágica cuando no hay anagnórisis o peripecia. Más imperfecta es aún cuando carece de final calamitoso y, sobre todo, cuando es doble y episódica — porque el placer de la variedad impide la contemplación de las cosas terribles-, y no verdadera - pues esta no genera los mismos efectos que cuando se sabe que los hechos contemplados han ocurrido en realidad-. Existen, por tanto, tragedias con final feliz. En la Poética se citan las dos Ifigenias y la Electra de Sófocles.

Aristóteles, en el libro octavo de la Política, explica la existencia de las tragedias con final feliz como una fase de la evolución del género que habría que atribuir a la impericia inicial del teatro. En los primeros momentos de la tragedia los poetas trataban de acomodar sus fábulas a los gustos del público y terminaban sus tragedias con final feliz porque los hombres acudían a los espectáculos para recrearse, y no para entristecerse. Con el tiempo se comprendió la mayor perfección que implicaba el final trágico de la fábula. La misma diversificación encontramos en la comedia, que se despoja a lo largo de la historia de la comicidad obscena y lasciva que la acompanó desde su origen. ${ }^{48}$

47. Compendio, pp. 242-243.

48. Compendio, pp. 244-245. 
El criterio de la evolución de los géneros según las costumbres y los tiempos, que será general entre los preceptistas españoles del siglo venidero, permite a Guarini una última justificación de la tragicomedia. La sociedad contemporánea no tiene necesidad de la tragedia para purgar el miedo o la compasión porque cuenta para este fin con los preceptos de la religión cristiana. ${ }^{49}$ De esta forma Guarini certifica la defunción de la tragedia clásica y se libera de la posición ambigua en la que la conciliación horaciana del docere y del delectare había mantenido a los intérpretes de Aristóteles. ${ }^{50}$

Podemos ya formular una definición de la tragicomedia que incluye la solución al problema de unidad de los fines. El fin de la tragicomedia es imitar con aparato escénico una acción fingida y mixta de todas las partes trágicas y cómicas que pueden estar juntas, corregidas bajo una única forma dramática, con el fin de purgar con el placer la tristeza de los espectadores. De este modo, el único fin mixto es el instrumental, que presenta elementos trágicos y cómico juntos, pero el fin arquitectónico es exclusivamente el cómico, que es el de librar al público de la melancolía. ${ }^{51}$ La tragicomedia es, pues, susceptible de una catarsis cómica ya no ética, sino puramente hedonística. Y no es, bajo ningún concepto, una tragedia risible, puesto que esta, sencillamente, no es una tragedia:

[...] la tragicommedia non ha gli affetti tragici accompagnati col riso; può bene avere alcune parti che sono atte a muoverli, ma non a purgarli, né tragici dir si possono, se non purgano; e se s'addimandasse se questi affetti sarebbono essi per sé bastevoli a purgare se'l riso se ne levasse, direi di no, mancando loro la compagnia dell'altre parti che possano star col riso, le quali senza dubbio non fôrano per se sole sufficienti a purgare gli affetti tragici. Laonde si conchiude che la tragicommedia non è tragedia ridente, non essendo in verun modo tragedia. (Compendio, p. 259)

Vale la pena detenerse ahora a considerar hasta qué punto esta rigurosa argumentación de Guarini ofrece un soporte teórico coherente a la labor de interpretación de la comedia nueva que gran número de estudiosos han llevado a cabo con relación al espinoso asunto de la tragedia en España. Ahora que hasta el más firme defensor de la existencia de un corpus de tragedias clásicas en España, Alfredo Hermenegildo (1991), ha parecido admitir la tesis de Froldi (1989) sobre las «experiencias trágicas» rápidamente absorbidas por el torrente de la comedia nueva, el debate se ha situado en la existencia de un género único, de naturaleza tragicómica, para el que se ha propuesto la denominación de drama. En este drama, la mayor o menor

49. Compendio, p. 245.

50. Cf. Bonora (1966: 95). Brancaforte (1975: xvII) señala también la filiación horaciana de Cascales en lo relativo a este asunto: «Con Horacio y tantos otros preceptistas insiste en que el fin de la poesía es agradar aprovechando. El concepto aristotélico de la catarsis es interpretado desde una perspectiva estrictamente moralista, como medio para alcanzar la virtud, subrayando asimismo el influjo que ejerce el miedo en nosotros».

51. Compendio, p. 246. 
presencia, la mayor o menor activación de aspectos sentidos como trágicos, en su mayoría de carácter contenidista o retórico, da lugar a lo que Canavaggio (1988) denomina «modulaciones peculiares dentro de un género flexible y poliforme». Oleza Simó (1994) prefiere escuchar el «rumor de las diferencias» que le hacen dividir la producción de Lope en dos macrogéneros, denominados comedia y drama, sustituyendo drama al término tradicional de tragicomedia por considerarlo más exacto, ya que la comedia española ocupó en buena medida el ámbito que la preceptiva destinaba a la tragedia, mientras que tomó una mínima parte del espacio reservado por la misma para la comedia. ${ }^{52}$ Estas modulaciones o este rumor de las diferencias tienen mucho que ver con este planteamiento que hace de la creación poética un minucioso arte combinatorio, casi de alquimia, entre elementos diversos cuya mayor o menor presencia en el compuesto nos permite distinguir, por un lado «obras dramáticas serias», algunas auténticas tragedias como El castigo sin venganza o El médico de su honra, las tragedias calderonianas o algunas comedias heroicas, hagiográficas y de gran espectáculo. Y, por otro lado, «obras dramáticas cómicas», que comprenden las comedias burlescas, el entremés y otros géneros cómicos breves, y la comedia de capa y espada, con sus variantes de comedia de figurón y comedia palatina.

\section{La unidad y las tragedias de doble acción \\ La mezcla de acciones diversas. La tragedia "a lieto fine» como justificación de la tragicomedia}

El segundo problema de unidad que plantea la tragicomedia es el relativo a la existencia de dos acciones diversas dentro de la obra — una que es una perfecta tragedia y otra que es una perfecta comedia, aunque la naturaleza de las acciones sea ahora secundaria-, fenómeno que Guarini, para establecer una distinción frente a la fábula mixta — en la que sí es pertinente la naturaleza cómica y trágica de las acciones-, denominará con el término de fábula injertada — nótese que es el término que emplea Tirso aunque se están refiriendo a fenómenos diversos-:

In duo modi può esser detto che nel poema del Pastor fido non sia servato il precetto della unità: l'uno per le due forme tragica e comica; l'altro, per avere piú d'un soggetto, come son quasi tutte le terenziane. Delle quali favole, acciocché noi co’ propri termini più spedito e più chiaro facciamo il nostro discorso, chiameremo la prima col nome solito mista, e la seconda innestata. (Compendio, p. 224)

El punto de partida del poeta es la autoridad de Terencio, la mayor parte de cuyas obras presenta una doble acción. El comediógrafo latino se dio cuenta de que la comedia simple resultaba demasiado pobre, y dado que los episodios son

52. En un trabajo posterior, Oleza (2012: 35) afirma que la oposición tradicional tragedia/ comedia fue sustituida por el par tragicomedia/comedia. 
partes constitutivas de todas las fábulas y, por lo tanto, son necesarios, llegó a la conclusión de que debían ser esenciales, nos construidos mediante parlamentos o personajes ajenos al argumento, sino por medio de nuevos objetos de la acción:

[...] niuno episodio si poteva aggiungere alla comedia che fosse né più proprio né più dilettevole né più artificioso di quello che contiene non parole sole, ma fatti, conducendolo e annodandolo con tant'arte e giudicio, che non contamini l'unità del soggetto, e, quello che tutto’mporta né può venir dagli altri episodi, annodasse maggiormente la favola, e'n conseguenza la rendesse molto più bella e più dilettevole. Queste fur le cagioni, questa l'origine della commedia innestata. (Compendio, p. 263)

El procedimiento, sin embargo, debía cumplir un requisito fundamental: los nuevos episodios debían estar unidos a la acción principal con arte y buen juicio, de manera que no quedase perjudicada la unidad del objeto, que es precepto inexcusable de Aristóteles. Para conocer si esta unidad ha sido preservada tenemos también un criterio claro: ninguna de las partes que componen la fábula puede ser eliminada o transformada sin que esta quede sustancialmente modificada..$^{53}$ El análisis tanto del Andria terenciana como de Il pastor fido a la luz de estas consideraciones demuestra que su unidad es perfecta. ${ }^{54}$

No tiene razón Denores cuando señala que los más autorizados autores clásicos han denunciado a Terencio por el uso de la fábula injertada — «favola doppia», dice él- en su Andria, a pesar de ser ambas de la misma naturaleza, esto es, cómica:

Pertanto se in una comedia non si permette che due azioni, et ambedue di persone private che conseguono il medisimo felice essito, e che non sono contrarie, siano mescolate insieme, del che è stato grandemente ripreso Terenzio [...], quanto meno si concederà che sia mescolata una favola comica con un'altra tragica, che sono fra se stesse dirittamente contrarie? (Discorso, p. 414)

Según Guarini, su oponente ha interpretado mal el prólogo de Terencio a la Andria, en el que el mismo autor da cuenta de estas críticas. Terencio no fue acusado de utilizar la doble fábula por mezclar en su obra los amores de Pánfilo y Carino, sino por haber incluido en su traducción de la Andria de Menandro una parte de otra comedia del mismo autor, la Perintia. Es decir, que lo que se condenaba en Terencio, era el uso de lo que los clásicos llaman la contaminatio. Sin embargo, Horacio, que ha de considerarse una autoridad mayor en materia literaria, alaba la abundancia de episodios en la obra del comediógrafo. ${ }^{55}$

Por otro lado, nadie ha declarado que en una fábula cómica no se puedan mezclar dos objetos cuando uno está injertado en el otro como episodio. A favor de la opinión contraria está el consenso de tantos literatos y el uso a lo largo

53. Poética, VIII, 1451a30-35.

54. Compendio, pp. 265-267.

55. Il Verato, fol. 35 r. 
de los siglos. La argumentación en defensa de la unidad de acción empuja a Guarini a otros terrenos literarios como son las acciones del romanzo. El poeta analiza la fábula del Orlando furioso y la encuentra más deleitosa y de acción más rica que la de la Ilíada, en la que se pueden individuar episodios completamente ajenos al objeto central y, por consiguiente, completamente evitables. ${ }^{56}$ El compuesto poético ha sido, pues, reconocido por Aristóteles, tanto en el drama como en la épica, siempre que respete un criterio de unidad: basta que las partes que componen la obra poética dependan verosímilmente entre sí. Este es, en definitiva, el fundamento teórico de la intriga secundaria que tanto puede enriquecer las comedias de Lope, circunstancia de la que él era muy consciente, como demuestra en el Arte nuevo (vv. 181-187).

La cuestión de la unidad en relación a la tragicomedia en Cascales, por el contrario, no va más allá de los estrechos márgenes de las unidades dramáticas, que son los más habituales:

Otros hay que hacen una comedia de una corónica entera; yo la he visto de la pérdida de España y restauración della. (Tablas poéticas, p. 201)

El punto de partida de Cascales, y con él de la mayor parte de los preceptistas españoles, es la reflexión sobre un aspecto muy debatido de la Poética, a saber, cómo se han de entender los distintos tipos de acción señalados por Aristóteles. El filósofo había distinguido una acción simple y una acción compleja y las había caracterizado en función de los elementos de la misma acción. ${ }^{57} \mathrm{La}$ tragedia de acción doble, o de doble constitución según otras denominaciones, que terminaba de manera opuesta para los personajes buenos y para los malos, fue considerada en un segundo grado de perfección por Aristóteles, ${ }^{58}$ circunstancia esta que fue aprovechada por Cascales para señalar la condena explícita de la tragicomedia por parte del estagirita, según hemos visto en los primeros textos citados del autor.

Guarini no pone en entredicho la validez del aserto aristotélico, sino que fundamenta su defensa en la advertencia de que no se debe confundir la fábula injertada con las tragedias de doble acción — comentadas en la Poética como tragedias imperfectas pero nunca condenadas,$-{ }^{59}$ ya que estas tienen un doble fin, mientras que la tragicomedia no tiene más que un único fin, y, en consecuencia, no puede ser rechazada según los principios aristotélicos, pues no se ve afectada por ellos. El fin único es feliz tanto para los personajes buenos - al igual que en estas tragedias de doble acción—, como para los malos — según costumbre de la comedia-, y en esto no coincide con la descripción de Aristóteles:

56. Il Verato secondo, pp. 284-291.

57. Poética, X, 1452a12-18.

58. Poética, XIII, 1453a.

59. Compendio, p. 258. 
E, come il riso non converrebbe alla doppia costituzione, conciosiacosaché, dov'egli è, non possa stare tragica forma, così il gastigo, che nella doppia a' malfattori si dà, non conviene alla poesia tragicomica, nella quale, secondo'l costume comico, i peggiori non si gastigano. (Compendio, p. 260)

La aceptación de finales felices en el seno de la tragedia de doble acción fue el expediente usado con más asiduidad para justificar un tipo de composición llamada en Italia tragedia a lieto fine - uno de cuyos principales cultivadores fue otro viejo conocido de la literatura espańola, Giraldi Cinzio-, e importada a España en auxilio de la justificación de la comedia nueva. Composición que, lógicamente, también generó su polémica, estudiada por Weinberg (1961: II, 912-918). El Abad de Rute, en su apología de la tragicomedia, interpretaba el texto aristotélico con absoluta libertad y justificaba la existencia no solo de tragedias sin final triste, sino también de comedias sin final alegre: ${ }^{60}$

[...] at vero Comoediae absque laeto exitu, et Tragoediae etiam absque tristi exito, seu exodo [...] et sua retinent nomina, et suum assequeuntur finem: in Tragoedia nanque à timore, misericordiáve delectationem per imitationem Poeta parat, teste Aristoteles, non igitur est necessarius assignatus ab aliquibus hisce Poematibus finis: retinere nomen patet: assequi finem per peripetias, agnitiones, et perturbationes, quae in illustrium virorum actionibus reperiuntur, satis apparet, intentum ergo habemus. Rursus neque tanquam complementum requiritur hilaris, aut lugubris finis, absque illo enim Comoedia, et absque hoc Traogedia perfectae sunt, nullo igitur modo requiritur.

Sin embargo, y a pesar del interés de esta observación, el Abad de Rute parece ignorar que Guarini va mucho más lejos, no ya evitando la tragedia de final feliz como argumento, sino estableciendo una neta distinción entre esta y el nuevo género tragicómico. Es cierto que Aristóteles admite una tragedia que no termina en catástrofe, pero esta no es sino una tragedia menos perfecta, por tener un final más propio de la comedia, que se opone a la tragedia perfecta de final infeliz. ${ }^{61} \mathrm{Y}$ la tragicomedia no es una tragedia, sino un nuevo género mixto.

Este nuevo género se opone por igual a la tragedia de doble acción y a la tragedia a lieto fine. Con respecto a la primera, la tragicomedia peca menos contra la unidad por tener un único fin proporcionado a las personas, tanto trágicas como cómicas, que en ella aparecen. Por lo que respecta a la segunda, la tragicomedia admite en su seno tanto a los personajes malos como a los buenos y unos no son menos principales que los otros, mientras que en la tragedia de final feliz los personajes malos son secundarios, y el único fin, de naturaleza cómica, obliga a que el autor los ignore a la hora del desenlace. ${ }^{62}$ Por estas razones

60. Tomo el texto de Newels (1974: 177).

61. Compendio, pp. 260-261.

62. Compendio, p. 261. 
Il pastor fido renunció desde el principio al título de tragedia al que, desde posturas contemporizadoras con el aristotelismo imperante, podría haber aspirado legítimamente:

E, benché con buona coscienza, per la gran somiglianza che ha l'una con l'altra, si fosse potuto, alcune cose mutandone, darle titolo di tragedia, fu però assai meglio ch'egli avesse il primo luogo nelle tragicommedie che'l secondo nelle tragedie, e che fosse una favola in genere tragicomico perfettissima, quantunque da meno reputata delle tragedie, più tosto che una tragedia degenerante e per non eccellente dal filosofo giudicata. (Compendio, p. 262)

De hecho, la tragedia con final feliz nunca dejó de considerarse una tragedia más y tuvo poco que aportar al debate sobre la mezcla de «lo serio» y «lo ridículo». Es más, después de Giraldi Cinzio apenas si se escribieron tragedias con final feliz, y su influjo se hizo sentir de forma más notoria en Francia e Inglaterra.

\section{Los personajes de la tragicomedia}

\section{Personajes grandes y personajes viles. Problemas de decoro. La dignidad del pastor literario. El reflejo de una sociedad heterogénea}

Otro de los grandes problemas a los que da lugar la tragicomedia es la presencia simultánea en la acción de personajes pertenecientes a la tragedia y a la comedia, al que nos hemos referido de forma accesoria en otro momento. El asunto es importante dado que las personas hacen la fábula:

Primieramente non ha alcun dubbio che le persone fanno la favola. Quando dunque si sarà veduto che Aristotile abbia nell'ordine delle buone tragedie posta la favola ch'egli chiama di doppia costituzione, composta di persone parte tragiche e parte comiche, crederò che l'assunto bastevolmente sarà provato. (Compendio, p. 255)

El mismo pasaje de la Poética que habla de la tragedia de doble constitución sirve para ilustrar esta materia, puesto que la tragedia de doble constitución lo es, precisamente, en función de sus personajes, al contener dos acciones, una de personajes grandes y otra de personajes viles, que se entremezclan en la fábula y motivan dos finales, uno alegre y otro triste. Aristóteles, ya lo hemos visto, considera legítimo este tipo de tragedias, aunque lo ponga en segundo lugar respecto a la tragedia perfecta:

[...] conchiudesi che la favola mista di parti tragiche e comiche sia posta dal filosofo nel secondo luogo delle tragedie, e'n conseguenza si debbia chiamar da lui legittima poesia, non approvata come perfetta, ma ricevuta come tragedia. (Compendio, pp. 258-259)

Hay tragedias que admiten la presencia de personas viles, que son propias de la comedia; pero estas no aparecen para que sean imitadas sus costumbres, 
sino porque sirven a las obras de los personajes grandes que son objeto de la imitación. Así, en el Edipo, se presentan en escena unos pastores para referir el nacimiento del protagonista y dar ocasión a su reconocimiento. Por otro lado, la serie de siervos, matronas, soldados y demás personajes que cumplen estas funciones no deben ser considerados personas viles, puesto que es muy verosímil e incluso necesario que los íntimos servidores de los grandes señores no sean hombres populares y pertenecientes al vulgo. Para Guarini es esta una exigencia del derecho de la naturaleza y de la misma razón. ${ }^{63}$

Frente a las consistentes reflexiones del poeta italiano, Cascales, que repite en las partes dedicadas a la comedia y a la tragedia la doctrina aristotélica con respecto a la conveniencia de los personajes y la imitación de sus acciones, trata el asunto de la mixtura de personajes en la tragedia de manera muy tangencial: apenas un apunte en el primero de sus textos citados. El preceptista admite, como era ya opinión general, que algunos textos puedan ser legitimados mediante el recurso a la tragedia de doble acción, pero se resiste a dar carta de naturaleza al nuevo género tragicómico.

La misma resistencia encontramos en su contestación a la epístola que González de Sepúlveda - lector, casi con toda seguridad, de alguno de los escritos polémicos de Guarini-, le envía con algunas dudas teóricas, entre ellas una referida a la presencia en ciertas obras de personajes humildes junto a personas propias de la tragedia. Su carta, con fecha de 1625 está recogida en las Cartas filológicas (III, 9). Plantea la siguiente cuestión:

¿No podrían las primeras personas ser ilustres, y ya que no ellas, en las segundas y humildes que ayudan a la acción, ponerse la risa? Porque no me parece necesario que ésta nazca siempre de la principal acción, sino de las episódicas, ni siempre de los hechos, sino de los dichos, los cuales no todas veces son indecentes a personas graves. (p. 213)

Además del archiconocido antecedente del Anfitrión, González de Sepúlveda alude a la ya algo añosa polémica sobre $I l$ pastor fido y al silencio legal de Aristóteles al respecto:

Esta imitación sin duda movió a Baptista Guarini, en su Pastor Fido, a llamar aquel poema tragicomedia. Y Aristóteles a este género de acción, si bien le da el inferior lugar entre las fábulas, no totalmente la excluye. ¿Hacen algo estas autoridades y ejemplos? (p. 214)

En sus respuestas Cascales (Cartas filológicas, III, 10) debe admitir la posibilidad de esta mezcla, en el seno de la doctrina aristotélica sobre la tragedia de doble acción y sobre la tragedia episódica, ${ }^{64}$ aunque no la acepta como justifica-

63. Compendio, p. 256.

64. Poética, IX, 1451b33-35. 
ción de la tragicomedia y, significativamente, soslaya toda referencia a Il pastor fido en su respuesta, e insiste en deslegitimar la comedia plautina como único ejemplo clásico del nuevo género.

La mayor atención al asunto en los polemistas italianos se debe a que la discusión parte de un texto con unas características muy específicas. Il pastor fido es una "tragicomedia pastoral» y, como tal, da lugar a discusiones sobre la dignidad y calidad moral del pastor. La fábula de la tragicomedia es representada por pastores, personajes que plantean un grave problema de decorum (Herrick 1962: 139). Siendo al mismo tiempo personajes cómicos y trágicos, Guarini ha de tener cuidado en Il pastor fido de no mezclar ambos caracteres en una misma persona. La argumentación del autor echa mano para esta cuestión de las convenciones literarias de su tiempo, al no encontrar nada al respecto en la Poética de Aristóteles.

Los antiguos pastores, en la edad primera del hombre, que los poetas llamaron "de oro», no fueron todos iguales. No existía la diferencia del siglo que le tocó vivir a Guarini entre ciudadanos y villanos, sino que todos los hombres eran pastores, pero unos eran ricos y otros pobres, unos eran más altos personajes y gobernaban a los demás y otros obedecían, tal como sucede dentro de una ciudad contemporánea. Los jefes de los pastores podían llamarse príncipes o sacerdotes según las costumbres, pero seguían siendo pastores, puesto que una cosa es el llamarse y otra el ser. Que una república de pastores compuesta de este modo es verosímil nos lo demuestra el hecho de que Aristóteles, entre los griegos, y Marco Varrón, entre los latinos, hayan dado testimonio de su existencia. ${ }^{65}$

Los pastores no son tampoco personajes viles y han aparecido con decoro en más de una tragedia. Con vestimentas pastoriles presentan Sófocles a Diana y Eurípides a Minerva. Su dignidad está más que demostrada por la abundancia de personajes ilustres que han sido pastores. Apolo, como escriben los antiguos, lo fue. Rómulo y Remo fueron educados como pastores por Fáustulo, guardián de los ganados reales. ${ }^{66}$

Además, y pasando a argumentos de más peso, los más grandes profetas y patriarcas del pueblo hebreo no tenían otro oficio que apacentar rebaños. Abraham, Moisés y el rey David fueron auténticos pastores, de nombre y de profesión. El mismo Jesucristo se ha manifestado a los hombres con el nombre de Buen Pastor. Con la autoridad que emana de tan altos ejemplos bien se puede afirmar que la vida pastoril es una condición humana muy capaz de producir personas ilustrísimas. Por esta razón la nobleza y los casos horribles en la pastoral no están lejanos de lo verosímil poético. Baste de ejemplo el caso de José, hijo del patriarca Jacob, y su desafortunada vida. ${ }^{67}$

65. Compendio, pp. 268-270.

66. Il Verato, fol. $52 \mathrm{v}$.

67. Compendio, pp. 270-271. 
No todos los pastores son buenos, lo cual atentaría sin duda contra el principio de verosimilitud. Pastores hubo en obras clásicas que fueron malos, aunque su maldad no fue la de la tragedia. Para Guarini, esta es un pecado que produce el terror; la maldad del pastor, por el contrario, es producto de un defecto y provoca a risa ${ }^{68}$ No en vano el mismo Aristóteles ${ }^{69}$ hizo derivar el nombre de comedia del término ко es empleado por Guarini en abono de su discurso mediante la asimilación extensiva de los pastores a los campesinos, creadores de la comedia.

Una última cuestión de la polémica causada por la presencia de los pastores en la tragicomedia es su supuesta inutilidad para el bien de la república. Para Denores, si el final de la fábula es próspero, como así sucede en la tragicomedia, se está invitando a abandonar la ciudad, con el consiguiente perjuicio que ello supone para la sociedad urbana:

Perciò che si egli si constituisce la favola pastoral col principio turbulento e col fin prospero, questo è un tacito invitar gli uomini a lasciar le città et ad inamorarsi della vita contidinesca, del che non ebbero già mai intendimento que' primi che poetarono. (Discorso, p. 415)

Guarini se burla de la influencia que su oponente atribuye a la pastoral y su pretensión de prohibir el género: siendo la villa una necesidad para el ocio del ciudadano, es absurdo que se intente prohibir las fábulas de pastores, porque habría que prohibir igualmente las mismas villas con todos sus habitantes y sus rústicas conversaciones. ${ }^{70}$

Todos estos argumentos resultarían ciertamente poco plausibles fuera del contexto que supone la exégesis de un libro tan sacralizado como la Poética de Aristóteles y de un ambiente fuertemente atado a convenciones literarias y culturales. Y, sin embargo, hemos de admitir su eficacia, de la que es testimonio en España Ricardo del Turia, cuando emplea, en su Apologético de la comedia española, la defensa de la dignidad de los pastores y otros personajes del campo para justificar las acciones de los lacayos, más propias de personas nobles o de buen juicio, que podían ser contempladas a diario en tantas comedias modernas: ${ }^{71}$

Y hacer fáciles dueños a los rudos pastores de materias profundas no desdice de lo que famosos y antiguos poetas han platicado, y por evitar prolijidad volvamos solo los ojos a la tragicomedia que el laureado poeta Guarino hizo del Pastor Fido, donde un sátiro que introduce (a imitación de los que en esta figura reprehendían los vicios de la república, de donde les quedó nombre de sátiras a los versos mordaces) habla de cosas tan altas y especulativas que es el mejor papel de la fábula [...].

68. Il Verato, fols. $47 \mathrm{r}-48 \mathrm{r}$.

69. Poética, $1448 \mathrm{a} 37$.

70. Il Verato, fol. 40r.

71. Cito por la ed. de García-Reidy (2015). El pasaje corresponde a los ff. A5r-v. 


\section{El estilo tragicómico y el decoro}

\section{La proporción entre la fábula y el estilo. La mezcla armónica de estilos. La lengua poética a escena. Prosa y verso. La lengua de los pastores}

El problema del decorum afecta asimismo y de manera muy especial a los aspectos formales de la tragicomedia, y muy en particular al estilo. Denores, que se negó con contumacia a reconocer alguna cualidad en Il pastor fido, condenó también su estilo por haber violado las prescripciones de Demetrio Falereo en su tratado Sobre el estilo. ${ }^{72}$

Guarini señala que el estilo de la tragicomedia, para ser proporcionado a la fábula, ha de ser mixto:

Ora, essendosi dalle parti e dal fine bastevolmente provato che il misto tragicomico è ragionevole, resta che ciò si pruovi ancor dallo stile, il quale, dovendo esser proporzionato alla favola, bisogna bene che, s'ella è mista, anch'egli, per essere uno, sia misto. (Compendio, p. 248)

El de Il pastor fido lo es, y lo demuestra recurriendo a las ideas de Dionisio de Halicarnaso, Hermógenes y el mismo Demetrio Falereo, que consideraban la posibilidad de distintos estilos dentro de un mismo género siguiendo un principio de armonía (Battistini y Raimondi 1984: 97). Este principio es ilustrado por el poeta con una comparación. Los estilos son como las cuerdas de un instrumento: cada una de ellas tiene un tono particular, pero el músico, mediante una mayor o menor extensión de cada cuerda, puede hacer que produzca el sonido en distintos grados de tonalidad. ${ }^{73}$

Demetrio Falereo distingue cuatro tipos de elocución: la humilde («dimessa»), la magnífica («magnifica»), la suave («polita») y la grave ("grave»). Los cuatro son susceptibles de diversas combinaciones. Los estilos humilde y magnífico y los estilos suave y grave no se pueden mezclar entre sí, pero nada impide que cada uno de ellos lo haga con otro estilo del par opuesto, como de hecho sucede en la tragicomedia. Su estilo propio y principal es el magnífico, que mezclado con el grave da la idea de tragedia, pero, acompañado del estilo suave, produce el temperamento que conviene al nuevo género. Al tratarse de personas grandes y de héroes, no conviene que se expresen humildemente; $y$, del mismo modo, dado que en la tragicomedia no tiene lugar lo terrible, ha de dejarse de lado el estilo grave para usar uno que dulcifique la grandeza y la sublimidad que son propias de la tragedia. ${ }^{74}$

El proceso de creación del nuevo estilo es, una vez más, la búsqueda de un equilibrio parecido a la mezcla de colores que lleva a cabo un pintor. Por un lado, según enseña Hermógenes, el autor debe moderar la gravedad de las sen-

72. Discorso, p. 414.

73. Compendio, pp. 248-249.

74. Compendio, p. 248. 
tencias con alguno de los modos que las suelen hacer humildes; por otro, la humildad debe quedar frenada con un poco de la nobleza en el hablar que es propia del estilo magnífico, de manera que la materia no se eleve tan alto como la tragedia, pero tampoco se acerque a la elocución cómica. ${ }^{75} \mathrm{La}$ tragicomedia se convierte así en un pastiche de estilos que pretende adquirir un valor armónico e idílico, próximo a un tono medio de naturaleza musical (Folena 1958: 348). Concepto similar al del estilo medio o natural, que tanto preocupó a Gracián - hasta el punto de añadir un tratado de los estilos en la segunda edición de la Agudeza - y que se remontaba al ideal erasmista de la lengua: un estilo forjado en un nuevo ejercicio de moderación, entre la elevación del estilo asianista, pulido de los excesos que llevan a la dificultad de la comprensión, y la contención del estilo de Tácito, que bordea el laconismo y asegura la preńez de la frase.

Una segunda acusación que dirige Denores contra Il pastor fido es el uso en la fábula pastoral del hablar figurado de los poetas líricos. Guarini responde que el mismo Aristóteles, en la parte de la Poética dedicada al tipo de expresión que conviene a cada género, atribuyó al verso dramático las voces metafóricas y adornadas. ${ }^{76} \mathrm{Si}$ el filósofo consideró que estas eran la principal virtud del drama, no hay razón alguna para que los críticos condenen el uso en Il pastor fido del hablar figurado, que no es otro sino el metafórico. ${ }^{77}$ En cuanto a si hay un tipo de ornamento que convenga más a la lírica y otro más adecuado para la dramática, no hay maestro de retórica o de poética que lo haya tratado y, por tanto, el poeta es libre de obrar según su propio criterio:

Quanto agli ornamenti lirici, se si trovasse maestro di ritorica o di poetica, che insegnasse quali sieno i particolari ornamenti del lirico e quali del drammatico, a loro sarei ricorso, e le leggi prendendone, con assai men di parole avrei condotta la mia difesa. (Compendio, p. 250)

Estamos aquí antes dos problemas diferentes pero estrechamente ligados. Por un lado, las discusiones sobre el uso del verso en escena, que se plantean como una lucha entre verosimilitud y el placer inherente a la expresión bella. El teatro se ha de escribir en verso para los preceptistas por la presión que ejerce la autoridad aristotélica, que no considera otra posibilidad, puesto que el estagirita elabora su doctrina a partir del análisis de una tradición teatral versificada. Sin embargo, el siglo Xvi conoce una amplia producción de comedias en prosa, en su mayor parte hijuelas de La Celestina, que prolongan la tradición de la comedia humanística. Es ilustrativo al respecto este pasaje de Quevedo en el prólogo a la Comedia Eufrosina: ${ }^{78}$

75. Compendio, p. 249.

76. Poética, XXII, 1459a11-14.

77. Compendio, p. 250.

78. Tomo el pasaje de Porqueras Mayo (1968: 151). 
Pocas comedias hay en prosa de nuestra lengua, si bien lo fueron todas las de Lope de Rueda, mas para leídas tenemos La Salvaga, y con superior estimación, La Celestina, que tanto aplauso ha tenido en todas las naciones. En portugués hay una de Camoens, dos del doctísimo Corte Real, y esta Eufrosina [...].

Esta circunstancia, sin embargo, parece no tener reflejo en los preceptistas de la época, que no van más allá de la propuesta, tomada de un oscuro pasaje horaciano, de redactar el argumento de la fábula en prosa en un primer momento para proceder después, una vez estructuradas sus partes y seleccionados sus elementos esenciales, a la pertinente versión en metro. Recomendación que, como sabemos, está también en el Arte nuevo de Lope, vv. 211-212. Pero aquí nos movemos también en terreno resbaladizo, porque tampoco hay un estudio de conjunto sobre posibles fundamentos teóricos que permitieron el uso de la prosa en géneros como el entremés y, ya en el siglo XVIII, de la misma comedia, mientras que siguieron ligando el cultivo de la tragedia a la versificación hasta el mismo siglo XIX.

Se comprende con estas reflexiones la importancia de la métrica en el conjunto de la teoría literaria, y no tanto por lo que atañe a la historia y caracterización de cada uno de los metros, que cuentan ya con el trabajo clásico de Díez Echarri (1970), como por la aceptación de su papel estructurante, a través de la adjudicación a cada tipo de metro de una situación dramática específica. Habría que recopilar las advertencias de uso del verso para la escena en los documentos de teoría dramática, aparte de los archiconocidos de Lope, especialmente los que no corresponden a un apartado de métrica en el seno de un texto mayor, sino los que son circunstanciales y se hallan dispersos. Muchos de ellos toman en consideración los problemas técnicos que el verso supone en la recitación de los actores.

El uso del verso planteaba un segundo problema de orden retórico, relativo a la ornamentación, que se va a ir ahondando a medida que avance el siglo con el debate en el terreno de la elocución lírica entre la claridad y la oscuridad de la lengua poética. Debate especialmente vigoroso en España a raíz de la difusión de los versos de Góngora, pero que tuvo también su espacio en Italia, por supuesto.

Sin embargo, en el momento que nos ocupa, esas polémicas todavía no han llegado. El estilo de Il pastor fido, según declara su autor, no presenta grandes ornamentos líricos, sino que sigue el modelo de Petrarca y su voluntaria dulzura, ajena al ritmo ditirámbico. Sus periodos no son largos ni duros porque Guarini prefiere la concisión y la claridad. Su elocución no pretende ser ni lejana de la lengua ordinaria, ni demasiado próxima al modo de hablar de la plebe. Al mismo tiempo, evita ser tan elaborada que no convenga a la representación, por excesivamente fatigosa para el espectador. ${ }^{79}$

No obstante lo dicho anteriormente, hay que decir que la preocupación por la lengua poética en escena tampoco es muy grande en los textos de teoría poética. Excepción notable en este sentido es González de Salas, que convierte su ilustra-

79. Compendio, p. 251. 
ción de la parte de la Poética relativa a la elocución en una diatriba contra los poetas «tenebrosos». ${ }^{80}$ Estamos, de todos modos, en 1633, fecha de publicación de la Nueva idea, y eso tampoco lo podemos olvidar. Las referencias al estilo pasan más bien por el planteamiento de un nuevo problema de decoro. Denores considera impropio de unos pastores un estilo tan ricamente adornado, ${ }^{81}$ pero Guarini sabe encontrar un principio de verosimilitud en la lengua de sus criaturas, aunque sea recurriendo una vez más a las convenciones literarias de su tiempo.

La rota explicativa de los géneros en la retórica medieval atribuía a las Bucólicas de Virgilio un estilo humilis, en consonancia con la naturaleza de sus protagonistas, pero lo cierto es que la tradición literaria vernácula, que había fundido la poesía pastoril clásica con el petrarquismo, había permitido su difusión en metros más propicios al estilo sublimis, como el endecasílabo, la octava o el soneto, empezando por la Arcadia de Sannazaro en Italia y siguiendo por Garcilaso en España. No en vano Herrera puso reparos a la égloga segunda de Garcilaso, no solo por lo que tenía de mezcla de géneros poéticos, sino por el empleo de registros que, a su entender, sobrepasaban lo conveniente para la materia pastoril. ${ }^{82}$

Il pastor fido se desarrolla en la Arcadia y, por tanto, no es maravilla que sus pastores embellezcan sus parlamentos con figuras poéticas en un lugar donde se encuentran en contacto constante con las Musas. Los habitantes de la Arcadia, además, como nos confirma Ovidio, tenían práctica constante con instrumentos musicales de varios tipos - y La Galatea cervantina es una buena demostración de esto mismo—, y así, no resultan extraños los ornamentos poéticos en personas que con tanta naturalidad manejaban el número y la armonía de la música ${ }^{83} \mathrm{El}$ principio que plantea Guarini, por lo que hemos podido comprobar, no es el de la verosimilitud retórica, sino el de una verosimilitud exclusivamente poética:

[...] così nel Pastor fido quelle vivezze, quegli ornamenti che lirici sono detti, non repugnano al verisimile (parlo del verisimile non retorico, ma poetico), essendo proprissimi di coloro che cosí parlano, né altramenti parlar saprebbono. (Compendio, p. 254)

De esta manera el poeta se distanciaba definitivamente de la poesía renacentista y del realismo, entendido como imitación de la verdad, que había sido su principal fundamento (Bonora 1966: 95). Es el mismo principio que va a permitir, en confluencia con otros factores que estudió Salomon (1985), el desarrollo literario de la figura del villano digno, que encontramos en tantas obras de Lope. Y si alguien se podía mover con conocimiento de causa en este polimórfico género era el Fénix, autor de los romances de Belardo y de relatos pastoriles, tanto en su versión sacra, como en su versión profana.

80. En la sección V de su Nueva idea de la tragedia antigua. Puede leerse en Sánchez Laílla (2015).

81. Discorso, p. 417.

82. Cf. las Anotaciones a la poesía de Garcilaso (2001: 800).

83. Compendio, pp. 253-254. 


\section{La égloga y el origen de la tragicomedia}

\section{La égloga como género mixto. Interferencias genéricas. La égloga, el drama satírico y la literatura pastoril. El difícil camino de un patrón explicativo}

Hemos hablado de literatura de pastores, de bucólica, y hemos aludido a la égloga, pero ahora hemos de volver a ella porque encierra algunas de las claves para la comprensión del problema de la tragicomedia. La égloga no era ni un diálogo ni un drama, pero en ella se reconocían ya unos rasgos esenciales de la forma teatral que, cuando alcanzó estructuras más complejas, hicieron posible que el género fuera condenado por los críticos más tradicionales. A lo largo de este periodo la égloga va a verse favorecida por un proceso de dignificación, que parecía reclamar convirtiéndose en un género omnipresente en las letras de este tiempo, y que tiene como hitos su inclusión por parte de Escalígero y Carvallo dentro los dramatica genera, la elevación de categoría que hace Pinciano al ponerla en relación con la bucólica virgiliana y su vinculación con la épica menor en Minturno y Cascales, y, muy singularmente, en las Soledades, donde Góngora confirmó, con su sentido lírico y su trasfondo heroico, la cercanía de su obra a los otros grandes géneros no dramáticos. No podemos olvidar tampoco la importancia que tuvo la vía alegórica para convertir al pastor en una figura a lo divino, notablemente en fray Luis y en san Juan de la Cruz, basándose en la prosapia bíblica a la que hemos hecho antes referencia - y que pudo llevar a los excesos condenados por Malón de Chaide en su Conversión de la Magdalena-.

El entendimiento de la égloga nos ha llegado en la crítica literaria enmarcada en el complejo mundo de la literatura de pastores. Los pastores invadieron la literatura renacentista en todas sus manifestaciones - poesía lírica, dramas, novelas, tratados cortesanos de amor-, e incluso traspasaron las barreras de la ficción para convertirse en moda social y motivo de divertimento cortesano ${ }^{84} \mathrm{La}$ teoría literaria, siempre atenta a la eclosión de nuevos fenómenos literarios, procuró hacer encajar la literatura de pastores en los patrones normativos vigentes.

A lo largo de los distintos apartados hemos tenido ocasión de apuntar la pertenencia de la tragicomedia al género pastoral, subrayada por Guarini al dedicar una parte de su exposición a trazar la línea genealógica que lleva de las obras clásicas a Il pastor fido, y para ello partía del principio de evolución y perfeccionamiento de los géneros que Aristóteles había puesto de manifiesto en la parte dedicada al origen de la tragedia. ${ }^{85}$

La pastoral, que es un género moderno, tiene su origen en la égloga y en la sátira de los antiguos. La égloga, al principio, consistía únicamente en un razonamiento entre dos pastores, en nada diferente a la escena que los latinos llaman

84. Véase López Estrada (1974).

85. Poética, IV, 1449a. 
diverbio, salvo en tener unidad y ser independiente, con principio y final en sí mismo. Teócrito fue el primero en hacer la égloga más grande de lo ordinario mediante la adición de varios personajes, una acción más compleja que la hasta entonces utilizada y la distinción de tiempos y lugares que es propia del poema dramático.

Sin embargo, el creador de la pastoral ha sido, en época contemporánea, Agostino Beccari con su Sacrificio (Venecia, Francesco de Rossi da Valenza, 1555) ${ }^{86}$ que ha transformado el género precedente como Sófocles y Esquilo lo hicieron con la tragedia. Beccari ha recogido muchos razonamientos pastorales bajo una misma fábula dramática, los ha dividido en actos con un principio, un medio y un final suficientes y proporcionados, con su nudo y desenlace, y los ha dotado del decoro necesario, dando lugar a una auténtica comedia. De esta manera nos ha dejado la pastoral tal y como la conocemos, con excepción del coro, que es invención posterior de Torcuato Tasso en su Aminta. ${ }^{87}$

La égloga es, pues, una pequeña pastoral, y la pastoral una égloga grande. La égloga, al hacerse pastoral, cambia de nombre, pero no de naturaleza, pues su especie es también la poesía dramática. Guarini, con estas consideraciones, nos quiere mostrar su dependencia respecto a los buenos maestros trágicos precisamente en lo que tuvieron de espíritu renovador en el arte poético. Si los autores clásicos trataron de mejorar los géneros, también lo pueden hacer los contemporáneos sacando la égloga de su infancia y llevándola a su madurez. Se trata de un aspecto más de la querella de antiguos y modernos que atraviesa todo el siglo Xvi y que es fundamental en la polémica en torno a la comedia nueva.

La teoría literaria española parece llevar otros derroteros. Su punto de partida son los comentarios de Herrera (1580) y el Brocense (1574) a las églogas de Garcilaso; y, en consecuencia, el género égloga se adscribe inmediatamente a la lírica. De hecho, las críticas más duras de Herrera a la Égloga segunda de Garcilaso están motivadas, como hemos visto, por el descubrimiento en ella de lo que el poeta sevillano estima elementos ajenos, no propiamente líricos, sino pertenecientes a la comedia, la tragedia o la elegía. Las opiniones de los comentaristas posteriores defraudan por su timidez y parquedad en un momento en el que la literatura de pastores ha alcanzado su pleno apogeo.

La conexión entre égloga y comedia nueva es inmediata, porque ambas presentan, en su realización literaria, una mezcla de componentes de distinta naturaleza genérica, que abarca desde los personajes y su desfase con la materia tratada a cuestiones de orden estilístico que afectan al decoro retórico. Pero esta conexión se hace todavía más pertinente desde el punto de vista de la teoría literaria. Como ha estudiado Egido (1985), la égloga, que alcanzó su mayoría de edad por encima de la teoría de los géneros y al margen por completo de la poética aristotélica, fue

86. Para esta obra fundamental, véase Borsari (2010).

87. Compendio, pp. 272-274. 
recibida también por los comentaristas como un auténtico género mixto, sobre todo por el uso de la prosa y el verso y por la ruptura de la rota virgiliana en los estilos. En cuanto al modo de la imitación, podía pertenecer tan pronto al género narrativo, como al dramático o al mixto, como demuestran las églogas de Garcilaso, porque en la tercera predomina la diégesis, mientras que la segunda es casi toda diálogo, y en la primera ambas formas se equilibran..$^{88}$

No se ha profundizado mucho, en la historiografía literaria española, en las relaciones entre el origen de la tragicomedia moderna y los dramas de tema pastoril, conexión más que evidente para los italianos, vista la naturaleza de sus primeras obras tragicómicas, y probablemente intuida por muchos, como demuestra el hecho de que Pedro Manuel Jiménez de Urrea pueda escribir una Égloga de la tragicomedia de Calisto y Melibea (1513). Esta circunstancia, la naturaleza pastoril de las primeras tragicomedias, hizo que, desde el primer momento, el nuevo género se beneficiase, a efectos de apoyo teórico, de la reflexión sobre otros géneros, menores pero de incuestionable prosapia grecolatina. Es el caso de Giraldi Cinzio - autor de Egle y de una Favola pastorale que inician la tradición culminada por Tasso y Guarini-, quien defiende sus propias creaciones con la redacción de una Lettera o Discorso sopra il comporre le satire atte alle scene (1545). ${ }^{89}$

En España nuestros teóricos tuvieron siempre el convencimiento de que se hallaban ante un género mixto más, aunque no lo emplearon de forma contundente como argumentación para defender la licitud de la tragicomedia, porque, como digo, les faltó un referente literario real y cercano al que poder arrimarse. Es cierto que en los orígenes del teatro castellano Juan del Encina, que había traducido las Bucólicas de Virgilio, recoge la tradición medieval de los tropos de pastores, aprende de los italianos las convenciones cortesanas de las églogas representables, ennoblece la figura del pastor rústico dotándola de sentidos alegóricos, morales e incluso políticos, y ensancha sus términos hasta escribir auténticas comedias como la Égloga de Plácida y Victoriano (c. 1520). Sin embargo, su labor se tiene que enfrentar al extraordinario éxito editorial de la novela pastoril, a partir de La Diana de Montemayor (1559), que va a cerrar el paso a la égloga representable y la va a circunscribir a ser un elemento más del nuevo género narrativo. Es la tesis de López Estrada (1974). Así, toda novela pastoril incluye algún momento en que los personajes alzan un tablado y representan una égloga. Ocurre en La Diana, ocurre en La Galatea, donde, en las bodas de Daranio, se representa un debate sobre quién sufre con más fuerza los embates de la adversidad en el amor; o en la Arcadia de Lope, con la égloga representada por Montano y Lucindo. En la novela pastoril, por tanto, la narración somete al género dramático y se apropia de sus personajes, de su poética y hasta de su nombre: égloga llama Cervantes a La Galatea, y la novela pastoril se convierte de

88. Para la teoría de la égloga en España, véase también Fosalba (2004).

89. Puede leerse en Giraldi Cinzio (1973). 
hecho en una égloga mixta, donde, además, por influjo de Sannazaro, se mezcla la prosa con el verso - cada pasaje en prosa termina con una égloga poética a modo de colofón que recitan los personajes-.

Lo mismo que hemos dicho sobre la égloga se podría aplicar a la sátira. Ya hemos visto cómo Giraldi Cinzio denominaba sus églogas como «sátiras representables" y la presencia de un sátiro como personaje esencial en Il pastor fido nos habla bien de la naturalidad con que estos genios campestres se movían entre pastores y pastoras. La tragicomedia y la sátira contemporánea presentaban rasgos muy divergentes en cuanto a su naturaleza y su temática, pero perduraba la memoria del primigenio carácter dramático de la sátira, muy vinculado además con el origen de la tragedia. En España no se ignoraron estas noticias historiográficas. Pero el establecimiento de una relación entre la comedia nueva como género mixto y la sátira estaba dificultado por un problema adicional, derivado de la identificación de la sátira con otro género doméstico de nuestro teatro como era el entremés.

Margarete Newels (1974: 153-156 y 193-197), la primera en ocuparse del lugar del entremés en el conjunto de la teoría literaria, ya señaló el aire de familia que los preceptistas le encontraron con relación a la sátira, a lo que se fueron ańadiendo otros factores. En primer lugar, los tratadistas relacionaron el entremés, considerado como unidad relativa en el curso del espectáculo, con un subgénero del teatro griego de breve extensión y con un contenido cómico burlesco que fue el drama satírico. Su función con respecto a la unidad mayor — en su caso la tragedia — era la de introducir una distensión en la solemnidad de la fábula y romper con el elemento burlesco la alta retórica del drama en el que se inserta. Por otro lado, la sátira, al igual que el entremés, despertó ya en la Antigüedad recelos morales por su carácter deshonesto.

También se equiparó a los mimos romanos, derivados de los sátiros griegos. Mimos y sátiros fueron una misma cosa para los preceptistas renacentistas y barrocos, y en España, fueron denominados indistintamente como mimos entremeses o mojigangas. Las analogías entre mimo y entremés se podían establecer según criterios formales, puesto que ambos iban intercalados entre las comedias y las tragedias, así como desde un punto de vista temático, ya que los dos eran géneros festivos y ridículos, y su acción era estrictamente cómica.

Como unidad integrada en la comedia, el entremés era también equiparable a los episodios de la fábula aristotélica. Para Pinciano, ambos elementos cumplen una serie de características, como su condición secundaria respecto de la fábula, su complementariedad necesaria desde el punto de vista estético con la misma fábula y su intención didáctica. No obstante, en la práctica, denunciada ya desde la Antigüedad, estos episodios fueron perdiendo su conexión con el drama para hacerse dependientes de una unidad teatral mayor, el espectáculo, al mismo tiempo que pasaban progresivamente a hacerse vehículo del delectare. Sucedió en la escena clásica con el coro, y sucedía también en la escena española con el entremés o la loa. 
Por último, y entendiendo el entremés como unidad dramática independiente, los tratadistas lo pusieron en relación con la comedia antigua. Así se refirió a él Lope de Vega en su Arte nuevo, vv. 69-71. Y el propio Lope, como también Castillo Solórzano, Salas Barbadillo y Quevedo dieron el subtítulo de comedia antigua a algunos de sus entremeses. En este sentido el entremés es el género cómico por antonomasia y se opone a la comedia nueva, que, por el contrario, no respeta las normas preceptivas.

\section{El término tragicomedia}

\section{El precedente plautino y la pertinencia del término. El precedente español de La Celestina. La "temible anfibología» de la palabra comedia}

Un último problema atañe al origen del mismo término tragicomedia y a la posible filiación histórica del nuevo género. Claro está que, en Italia, esta última tiene su importancia porque se parte de un género concreto como es el pastoral, al que Guarini considera heredero directo de la égloga y de la sátira de los antiguos. El autor defiende que la suya es la primera obra moderna que se ha presentado bajo ese nombre, y trata de dar razón de su uso trazando la historia de la denominación del género, para el que se emplearon términos como "commedia», «favola pastorale», «favola di pastori» o "pastorale». ${ }^{90}$ Beccari había denominado su Sacrificio como "favola pastorale». Por las personas privadas, la risa y el final feliz, su obra era una verdadera comedia, pero renunció a llamarla de este modo porque podría resultar impropio para una acción que se desarrollaba en el campo y cuyos personajes no representaban a ciudadanos. Por ello empleó el término genérico de fábula y le añadió el adjetivo pastoral, para indicar la condición de sus personajes. Con el tiempo el adjetivo adquirió la fuerza y el significado del sustantivo y pasó a indicar por sí mismo el concepto de «acción o fábula de pastores».

El título de Il pastor fido, que incluye la denominación específica de «tragicomedia pastoral», dejando de lado el término genérico de fábula, es explicado por Guarini como una forma de mostrar a las claras la cualidad de la fábula misma y su naturaleza mixta. No podía ser ni «comedia» ni «tragedia» porque un mixto no puede tener la misma definición que cada una de sus partes. Por otro lado, "pastoral» está para indicar que sus personajes son pastores y no ciudadanos.

No hay, por tanto, tres fábulas diversas en Il pastor fido, una de personas privadas que llevan el peso de la acción cómica, otra de personajes grandes que protagonizan la parte trágica, y una tercera de pastores que hacen la pastoral, sino una fábula sola de pastores, mixta de tragedia y comedia, y tejida cómicamente, que es un único poema. ${ }^{91}$

90. Compendio, pp. 273-274.

91. Compendio, p. 274. 
La tragicomedia fue conocida en la Antigüedad con otro nombre. ${ }^{92}$ Guarini cita a Rintón de Siracusa, cultivador de un género denominado "hilarotragedia», no señalado por Aristóteles por ser posterior a su Poética. Prátinas de Fliunte, por otra parte, en la época de Esquilo, inventó la sátira, a la cual hace mención Horacio (Ars poetica, 220-250), y que puede ser considerada un precedente de la tragicomedia moderna.

No se le escapaba esta relación genealógica a Denores, quien, de hecho, propone el nombre de "sátira» como el más adecuado para Il pastor fido. No obstante, este nombre es rechazado por Guarini al considerar que las sátiras son demasiado disolutas y carecen del decoro que la moderada fábula pastoral requiere. ${ }^{93}$ El poeta prefiere denominar su obra como "tragicomedia" porque cuenta con un precedente ilustre: Plauto, queriendo mezclar dos acciones en su Anfitrión y temiendo ser acusado de incluir personas grandes en una materia cómica, renunció a llamarlo comedia y le dio el nombre de tragicomedia, que es el que mejor recoge su naturaleza mixta. ${ }^{94}$ En realidad, nadie antes de Guarini había puesto en relación el Anfitrión de Plauto con el resto de las obras reconocidas como antecedentes del género, como el Cíclope de Eurípides y otros dramas satíricos (Herrick 1962: 7). Esta circunstancia parece deberse a la identificación de las prescripciones de Horacio sobre el drama satírico con la tragicomedia.

Denores reconoce efectivamente la fuente del término en la obra plautina, y en su Apologia añadiría también una referencia a La Celestina - "un'altra spagnuola intitolata Calisto e Melibea», fol. 29r-, aunque no admite ninguna de las dos, despertando así el impulso reivindicador del Abad de Rute: ${ }^{95}$

[...] quiso también él, un extranjero, meter la hoz en la mies ajena (quiero decir en la lengua espańola) y condenar igualmente una obra que todos los nuestros admiran y que elogian cuantos extranjeros conocen nuestro idioma, esto es, la Tragicomedia de Calisto y Melibea, que vulgarmente llamamos Celestina, y aunque yo pudiera encargarme de su defensa y no perdería, según creo, la causa, [...] juzgué preferible, sin embargo, unirme a aquellos que se ocuparon o se ocuparán más adelante de la justísima defensa de la tragicomedia de Guarini, ya que Nores censura las dos igualmente.

La misma actitud negativa de Denores caracteriza a Cascales, en el que hemos podido comprobar una pertinaz recusación del término y de su fuente, en el segundo de sus textos citados. Cascales es muy parco en el uso de la palabra "tragicomedia». Sin embargo, muchos factores nos indican que se está refiriendo al nuevo género bajo otros nombres y, en concreto, bajo el genérico de "comedia». De esta forma se entiende cuando lo pone en relación con la obra de Lope

92. Il Verato, fols. 30v-31v.

93. Il Verato, fol. $31 \mathrm{v}$.

94. Compendio, p. 274.

95. Cito por la traducción de Marín López (1988: 47). 
de Vega en la epístola antes comentada (Cartas filológicas, II, 3). Lo mismo sucede en las Tablas poéticas:

A lo que imagino, ancho campo tenéis donde correr agora en la comedia, que es lo más practicable que tenemos de la poesía y adonde más exercitados están los poetas españoles. (p. 203)

No cabe duda de que está señalando la comedia nueva, que imperaba ya en los escenarios españoles. Por lo que respecta a la sátira, renuncia a establecer cualquier conexión del nuevo género con la práctica dramática antigua, desde el momento en que solo considera su moderno valor:

No os diré de la sátira antigua iámbica porque ya está escluyda por la lei y por el tiempo. (p. 180)

El marbete de "tragicomedia» usado por Plauto responde, a juicio de Cascales, a una intención jocosa:

Y si Plauto la llama tragicomedia, es por modo burlesco, que más atrás se declara y da a entender que habla de burlas [...] (p. 232)

El problema específicamente español de la adopción de comedia como término universal para hacer referencia a un género mixto, es el de convertir, como ha señalado Díez Borque (1989), la producción dramática del Siglo de Oro en un continuum ajeno a criterios de pureza genérica que los críticos renuncien a compartimentar. Ya hace algunos años algunas voces se alzaron para reclamar la necesidad de poner un orden en esta especie de jigote en que se había convertido la comedia nueva, sobre todo, por parte de aquellos que seguían la pista de la posible o imposible tragedia española, que dieron lugar a etiquetas como la «tragedia al estilo español» o la "tragedia nueva» de Hesse (1977). Sin embargo, con posterioridad a estas consideraciones, hemos asistido a serios esfuerzos por encontrar diferencias dentro del conjunto que permitan establecer un sistema de subgéneros en el seno de este monstruo literario y supere lo que Vitse (1995) llamó «la temible anfibología de la palabra Comedia». El mismo Díez Borque (1988) plantea la superación de una tipología de la comedia del siglo xvi basada en los criterios temáticos habitualmente empleados, y propone una clasificación que tome en cuenta los mecanismos básicos de composición de la comedia. Existe, a su juicio, en cada drama, un calculado diseño, estructurado en torno a unos mecanismos «fijos» que tienen muy en cuenta el modo y la forma de la recepción, y que permiten hablar con propiedad de subgéneros perfectamente delimitados como la comedia de capa y espada. Subgéneros que, por otro lado, estaban en la conciencia de los que escribieron en el siglo XvII sobre el teatro contemporáneo, porque no es raro encontrar referencias a comedias de capa y espada, comedias de divinas apariencias o comedias de espectáculos. En esta línea se han producido aportaciones sustanciales, 
en lo que podríamos llamar el desarrollo de la poética de los subgéneros cómicos (Vitse 1995: 280) — tarea extremadamente compleja por la ingente cantidad de materiales sometidos a estudio-, como la delimitación de un subgénero llamado comedia palatina, que tiene también su versión cómica y su versión seria, la comedia hagiográfica, o la comedia de figurón (Pedraza Jiménez y González Cañal 1996 y 1998). En todo caso, parece claro que una cierta taxonomía tiene ventajas metodológicas evidentes. ${ }^{96}$

\section{Conclusiones}

Limites de la reflexión sobre el género en España. La superación de Aristóteles y la vía inductiva

Varias conclusiones podemos extraer de lo aquí expuesto. Los pensadores de la época tuvieron que construir un soporte teórico para el nuevo género de la misma forma que lo habían hecho para la comedia. La tarea era difícil pero no imposible. En primer lugar, el género era novedoso, aunque no tanto, pues ya estaba recogido nominalmente en textos clásicos. Hubo que esperar, sin embargo, a que los preceptistas tuvieran que hacer frente a la producción efectiva de obras nacidas como tales tragicomedias. La falta en primera instancia de un corpus lo suficientemente significativo hacía muy difícil la especulación. No podemos olvidar que la preceptiva aristotélica era originalmente el resultado de la observación empírica de una literatura previa.

Además, los preceptistas tuvieron una serie de dificultades añadidas, como las derivadas del hecho de que ya no se tratase de un sistema bipolar con dos entidades opuestas, en esencia y accidente por accidente. La tragicomedia debía abrirse espacio entre los géneros previos, con los que compartía rasgos y, aparentemente, finalidades. La solución consistía en individuar los elementos de la comedia y la tragedia susceptibles de ceder en la integridad de su condición para que se produjese el acercamiento que da lugar al género mixto que es la tragicomedia. Después había que buscar una finalidad autónoma que diera carta de naturaleza definitiva al nuevo género. En estas condiciones es comprensible que la exposición teórica de la tragicomedia no esté tan estructurada y cerrada como la de la tragedia, o incluso la de la comedia, pero no podemos dar por sentada su intranscendencia.

Con todo, se produjeron justificaciones teóricas tan sólidas como la de Giambattista Guarini. Que no haya en España un documento de este calibre no puede ocultar que la comedia nueva fuera recibida como tragicomedia y que se multiplicasen entre nuestros críticos, de manera ciertamente dispersa y asistemática, los argumentos esgrimidos por Guarini, Denores y sus respectivas cohortes de apologistas.

96. Véase la síntesis genérica de Oleza Simó y Antonucci (2013). 
La poética de Guarini puede parecer a simple vista el fin de la teoría de los géneros, pero no debemos dejar pasar inadvertido el carácter profundamente aristotélico de su pensamiento crítico. Se ha demostrado que, en el arte de la poesía, no se crea, sino que se compone, y por este principio se abre el camino a la codificación de nuevos géneros, de los cuales Il pastor fido es el ejemplo más notable. Guarini no rechaza el concepto de género literario, sino que sustituye sus principios universales e inalterables por un criterio de relatividad histórica que ya había servido a Giraldi Cinzio para legitimar el poema caballeresco (Battistini-Raimondi 1984: 94). Si los autores clásicos trataron de mejorar los géneros, como así lo reconoce Aristóteles en el caso de la tragedia, también lo pueden hacer los contemporáneos, llevando la égloga a su madurez en la tragicomedia.

Por último, el Compendio de Guarini, con la inclusión en un único organismo coherente de elementos de diversa procedencia, constituye la primera poética barroca, nacida como una sólida armadura teórica para proteger la frágil estructura de la tragicomedia (Folena 1958: 345), al margen de que sus argumentos nos puedan parecer más o menos plausibles desde una óptica moderna. Sin embargo, no podemos dejar de valorar la importancia de las discusiones, ejemplo de las limitaciones de la Poética como sistema que pretende abarcar la globalidad de la creación literaria. Lo cual no evita que ninguno de los preceptistas de la época pueda prescindir de su magisterio, tratando precisamente de disolver las discrepancias entre el texto aristotélico y la nueva realidad de las obras contemporáneas; y ya hemos visto además que el modo de argumentar de Guarini fue el resultado de una profunda asimilación de la lógica aristotélica (Bonora 1966: 651).

El mismo respeto al aristotelismo puede ser la causa de que Francisco de Barreda, en su «Invectiva a las comedias que prohibió Trajano y apología por las nuestras», ${ }^{97}$ a la altura del año 1622 , y desde posturas más iconoclastas, considere insuficientes los logros artísticos sostenidos por el consistente ejercicio demostrativo del italiano:

Hagamos lo que Italia, que, teniendo ingenios, pierde por obediente a la edad pasada la gloria que le prometía la venidera. No se atreven a salir de aquellos claustros; son inviolables aquellos muros. No es acertado en su opinión lo que no es imitado, y no echan de ver que si los mesmos a quien atados imitan hubieran sido cobardes y hubieran guardado las huellas de los primeros, quedaran tan cortos como ellos. Crece el arte con el tiempo; él le alienta, él le cría. Él sobre sus hombros le pone en la cumbre de la perfección. Deposita sus tesoros en el atrevimiento. [...] Grande ingenio prometen a sus autores el Pastor Fido y el Aminta. Grande y digno de admiración; pero temeroso y acobardado. No tuvieron ánimo para sacudir el yugo de la antigüedad.

97. Es uno de los discursos incluidos en Elmejor príncipe Trajano: su filosofia politica, moral yeconómica deducida y traducida del panegírico de Plinio, ilustrado con márgenes y discursos, Madrid, Viuda de Cosme Delgado, 1622, fols. 125r-141v. Cito por Sánchez Escribano y Porqueras Mayo (1972: 223-224). 
A la vista de lo expuesto podemos entender qué lejos está Cascales, veinte ańos más tarde, de admitir en toda su amplitud la trascendencia de la perspectiva histórica en los estudios de poética, a pesar de ser ya testigo del profundo cambio en los gustos del público y de los autores de su tiempo. Por encima de todo queda el respeto absoluto e inquebrantable a las enseñanzas de los clásicos:

Y si bien éssos, por mostrar que valen mucho, con su ingenio y doctrina pretenden introduzir nueva poética en el mundo, al fin no serán de tanta autoridad que se deva creer antes a ellos que a Aristóteles y Horacio. (Tablas poéticas, p. 62)

Queda, por último, el deber de explicar por qué hemos señalado a la tragicomedia en el título de este trabajo como problema de exégesis sin resolver. La respuesta es sencilla: al contrario de lo que sucedió con la tragedia o la comedia, géneros para los cuales nuestros pensadores lograron desarrollar coherentes teorías explicativas, con respecto a la tragicomedia, en España no se pasó de ocasionales tanteos —algunos de los cuales hemos presentado aquí-, con argumentaciones de segunda mano y muy levemente fundamentadas en el texto aristotélico. Hubo una renuncia no expresa, pero muy temprana, a plantear el nuevo fenómeno literario de forma sistemática en términos de su acomodación o no a los patrones literarios aristotélicos. De hecho, para algunos críticos como Marc Vitse (1988) y David H. Darst (1986), el rechazo de Aristóteles es el hecho que separa de forma más radical a los nuevos dramaturgos del siglo XviI tanto de sus predecesores como de los teóricos académicos contemporáneos. En contraposición se adoptó con naturalidad un método inductivo a partir del impresionante caudal dramático que llenó los escenarios de este tiempo. La teoría literaria espańola sobre la tragicomedia se construyó a base de intuiciones y esporádicas argumentaciones, pero siempre a posteriori, porque, a diferencia de los italianos, los tratadistas contaban ya con un objeto de estudio de fronteras incluso excesivamente dilatadas. Se trata, por tanto, de una teorización de "posceptos", en términos de Vitse, fea palabra, pero muy significativa de este planteamiento. El mejor ejemplo de esta actitud es, sin duda, el Arte nuevo de Lope de Vega, pero no podemos olvidar otros ejemplos ilustres como la Idea de la comedia de Castilla de José Pellicer y Tovar (1635), «deducida — como reza el título- de las obras cómicas de Juan Pérez de Montalbán». ${ }^{98}$ En todo caso, y a nuestro modesto entender, aquí radica la tan traída y llevada inferioridad de nuestros pensadores con respecto a los italianos. Tómese este trabajo como aportación documental en sufragio de los prejuicios sobre el valor real de nuestra poética.

Nosotros, para intentar alguna solución, tenemos que recurrir a las palabras de Giambattista Guarini, cuyo principal mérito es haber salvado para la posteridad un género que, en boca del mismo autor, «vive lodato, amato, letto».99

98. Publicado en Lágrimas panegíricas a la temprana muerte del gran poeta Juan Pérez de Montalbán, Madrid, Imprenta del Reino, 1639.

99. Il Verato secondo, p. 302. 


\section{Bibliografía}

Abdulla, Adnan K., Catharsis in Literature, Bloomington, Indiana University Press, 1985.

Albalá Pelegrín, Muriel, «El Arte nuevo de Lope de Vega a la luz de la teoría dramática italiana contemporánea: Poliziano, Robortello, Guarini y el Abad de Rute», eHumanista, 24 (2013).

Alonso Veloso, María José, «Apuntes sobre la "crítica literaria" en España en las primeras décadas del siglo XVII", Analecta malacitana, 34, 2 (2011), 355396.

Arellano, Ignacio, «Teoría dramática y práctica teatral: sobre el teatro áulico y político de Bances Candamo», Criticón, 42 (1988), 167-193.

-, «Lo trágico y lo cómico mezclado: de mezclas y mixturas en el teatro del Siglo de Oro", RILCE, 27/1 (2011), 9-34.

Battistini, Andrea y Ezio Raimondi, «Retoriche e poetiche dominanti», Letteratura italiana, III. Le forme del testo, ed. Alberto Asor Rosa, Torino, Giulio Einaudi Editore, 1984, 439-518.

Bonora, Ettore, «Il classicismo dal Bembo al Guarini», Storia della letteratura italiana, IV: Il Cinquecento, ed. E. Cecchi y N. Sapegno, Milán, Garzanti, 1966, 627-652.

Borsari, Elisa, «Dal primo al secondo Sacrificio del Beccari, una favola pastorale a cavallo della Controriforma», Cuadernos de Filología Italiana, 17 (2010), 101-126.

Brancaforte, Benito, ed., Tablas poéticas de Francisco de Cascales, Madrid, Espasa-Calpe S.A. (Clásicos Castellanos), 1975.

Brognoligo, Gioachino, ed., Il pastor fido e il Compendio della poesia tragicomica, Bari, Laterza, 1914.

CANAVAGGio, Jean, «La tragedia renacentista española: formación y superación en un género frustrado", VIII Academia Renacentista. Literatura en la época del Emperador, ed. Víctor García de la Concha, Salamanca, Universidad de Salamanca, 1988, 181-195.

Carvallo, Alfonso de, Cisne de Apolo, ed. Alberto Porqueras Mayo, Kassel, Edition Reichenberger, 1997.

Conde Parrado, «Invectivas latinescas. Anatomía de la Expostulatio Spongiae en defensa de Lope de Vega», Castilla. Estudios de Literatura, 3 (2012), 37 93.

Couderc, Christophe, «Fronteras genéricas: Lope de Vega ante la tragicomedia», Criticón, 122 (2014), 67-82.

Darst, David H., "Teorías de la comedia en el Siglo de Oro», Boletín de la Biblioteca Menéndez y Pelayo, 62 (1986), 17-36.

Denores, Giason, Discorso intorno a que principii, cause et accrescimenti che la comedia, la tragedia e il poema eroico ricevono dalla filosofia morale e civile, $e$ da' governatori delle reppubliche, Padua, Meietti, 1586. 
Denores, Giason, Apologia contra l'auttor del Verato, Padua, Meietti, 1590.

Díez Borque, José M.a , "Mecanismos de construcción y recepción de la comedia española del siglo Xvir. Con un ejemplo de Lope de Vega», Cuadernos de teatro clásico, 1 (1988), 61-81.

—, «Teatralidad y denominación genérica en el xvi: propuestas de investigación", El mundo del teatro español en su Siglo de Oro: Ensayos dedicados a John E. Varey, ed. J. M. Ruano de la Haza, Ottawa, Dovehouse, 1989, 101-118. Díez Echarri, Emiliano, Teorías métricas del Siglo de Oro. Apuntes para la historia del verso español, Madrid, CSIC, 1970.

EgIDo, Aurora, “"Sin poética hay poetas”. Sobre la teoría de la égloga en el Siglo de Oro», Criticón, 30 (1985), 43-77.

—, «Heráclito y Demócrito. Imágenes de la mezcla tragicómica», Teatro español del Siglo de Oro: teoría y práctica, ed. Christoph Strosetzki, Frankfurt am Main / Madrid, Vervuert / Iberoamericana, 1998, 93-134.

Elvira, Muriel, «El Apologético de las comedias españolas a nueva luz», Criticón, 125 (2015), 93-106.

—, «Des polémiques italiennes aux polémiques espagnoles. L’abbé de Rute, lecteur de Guarini et de Denores", Rivalités de plumes entre Espagne et Italie, $X V^{e}-X V I I^{e}$ siècles, París, Classiques Garnier, 2018, 93-134.

EnríQuez, Feliciana, Tragicomedia Los jardines y campos sabeos, Lisboa, Pedro Craesbeeck, 1627.

FERri Coll, José María, «Cascales frente a Lope en la polémica sobre la tragicomedia", Anuario Lope de Vega, 15 (2009), 75-87.

FolenA, G., «La mistione tragicomica e la metamorfosi dello stile nella poetica del Guarini», La critica stilistica e il barocco letterario. Atti del II Congresso Internazionale dell'Associazione Internazionale per gli Studi di Lingua e Letteratura Italiana. (Venezia, 1956), Florencia, Le Monnier, 1958, 344-349.

Fosalba, Eugenia, "Teoría y praxis de la égloga en el siglo XvI», en Idea de la lírica en el Renacimiento (entre Italia y España), coord. Cesc Esteve y María José Vega Ramos, Pontevedra, Mirabel Editorial, 2004, 261-296.

Froldi, Rinaldo, Lope de Vega y la formación de la comedia, Salamanca, Anaya, 1968.

-, "Considerazioni sul genere tragico nel Cinquecento spagnolo", Symbolae Pisanae. Studi in onore di Guido Mancini, ed. Blanca Perinán y Francesco Guazzelli, Pisa, Giardini Editori e Stampatori, 1989, vol. I, 209-217.

García Berrio, Antonio, Formación de la teoría literaria moderna, 2. Teoría poética del Siglo de Oro, Murcia, Universidad de Murcia, 1980.

García-Reidy, Alejandro, ed., Apologético de las comedias españolas de Ricardo del Turia, Les idées du théatre, 2015, 20-11-2018 <http://idt.huma-num.fr/ notice.php?id=427>.

García Soriano, Justo, ed., Cartas filológicas de Francisco de Cascales, Madrid, Espasa-Calpe S.A. (Clásicos castellanos, 103, 117 y 118), 1952-1954, 3 vols. García Yebra, Valentín, ed., Poética de Aristóteles, Madrid, Gredos, 1974. 
Giraldi Cinzio, Giambattista, Scritti critici, ed. Camillo Guerrieri Crocetti, Milán, Marzorati, 1973.

GonzÁlez-BArrera, Julián, "Expostulatio Spongiae». Fuego cruzado en el nombre de Lope, Kassel, Edition Reichenberger, 2011.

GrüNnAGEL, Christian, "La genealogía alegórico-monstruosa de la comedia nueva según Lope y su entorno. Una interpretación en clave estética», Cuatrocientos años del "Arte nuevo de hacer comedias" de Lope de Vega (Actas selectas del XIV Congreso de la Asociación Internacional de Teatro Español y Novohispano de los Siglos de Oro, Olmedo, 20 al 23 de julio de 2009), ed. Germán Vega García-Luengos y Héctor Urzaiz Tortajada, Salamanca, Ayuntamiento de Olmedo / Sociedad Estatal de Conmemoraciones Culturales, AINTENSO, Universidad de Valladolid, 2010, 599-608.

Guarini, Giambattista, Il Verato ovvero difesa di quanto ha scritto messer Giason Denores contro le tragicommedie et le pastorali in un suo discorso di poesia, Ferrara, Vicenzo Galdura, 1588.

—, Il Verato secondo ovvero replica dell'Attizzato Accademico ferrarese in difesa del Pastor fido contra la seconda scrittura di Messer Giason de Nores intitolata Apologia, Florencia, Filippo Giunti, 1593.

-, Compendio della poesia tragicomica, tratto dai duo Verati, per opera dell'Autore del Pastor fido, colla giunta di molte cose spettanti all'arte, Venecia, Battista Ciotti, 1601.

Hathaway, Baxter, "A Purgation of Passions", The Age of Criticism: the Late Renaissance in Italy, Ithaca-New York, Cornell University Press, 1962, 203-300.

Hermenegildo, Alfredo, "Hacia una descripción del modelo vigente en la práctica dramática del siglo Xvi español», Crítica hispánica, 7 (1985), 43-55.

—, «Experiencias dramáticas y públicos teatrales: la tragedia española del Renacimiento", Nascita della tragedia di poesia nei paesi europei. Atti del XIV Convegno Internazionale. (Vicenza, 17-20 maggio 1990), ed. M. Chiabò y F. Doglio, Roma, Centro Studi sul Teatro Medioevale e RinascimentaleAccademia Olimpica, 1991, 261-282.

Herrera, Fernando, Anotaciones a la poesía de Garcilaso, ed. Inoria Pepe y José María Reyes, Madrid, Cátedra, 2001.

Herrick, Marvin Theodor, Tragicomedy. Its Origin and Development in Italy, France and England, Urbana, University of Illinois Press, 1962.

Hesse, Everett W., «Perspectivas sobre la tragedia en el Siglo de Oro», Interpretando la comedia, Madrid, Porrúa Turanzas S.A., 1977, 153-175.

José Prades, Juana de, ed., El arte nuevo de hacer comedias en este tiempo, Madrid, CSIC, 1971.

KIтto, H. D. F., "Catharsis», The Classical Tradition. Literary and Historical Studies in Honor of Harry Caplan, ed. Luitpold Wallach, Ithaca-New York, Cornell University Press, 1966, 133-147.

López Estrada, Francisco, Los libros de pastores en la literatura española. La órbita previa, Madrid, Gredos, 1974. 
—, «Del dramma pastorale a la comedia española de gran espectáculo: la versión española de Il Pastor Fido de Guarini por tres ingenios (Solís, Coello y Calderón)», Actas del IX Congreso de la AIH (18-13 de agosto de 1986, Berlín), Frankfurt am Mein, Vervuert Verlag, 1989, vol. I, 535-542.

—, «Poética barroca. Edición y estudio de los preliminares de El Pastor Fido de Guarini, traducido por Isabel Correa (1694)", Hommage à Robert Jammes, ed. Francis Cerdan, Toulouse, Presses Universitaires du Mirail, 1994, vol. II, 739-753.

López Pinciano, Alonso, Philosophía antigua poética, ed. Alfredo Carballo Picazo, Madrid, CSIC, 1973, 3 vols.

Marín López, Nicolás, «El humanista Don Francisco Fernández de Córdoba y sus ideas dramáticas», Estudios literarios sobre el Siglo de Oro, ed. Agustín de la Granja, Granada, Universidad de Granada, 1988, 41-63.

Maurel, Serge, L'univers dramatique de Tirso de Molina, Poitiers, Publications de l'Université de Poitiers, 1971.

McGaнA, Michael, "Guarini’s Il Pastor Fido and Lope de Vega's El verdadero amante», Journal of Hispanic Philology, X, 1 (1985), 51-60.

Meunier, Philippe, «La réponse de Lope de Vega à Aminta et $I l$ pastor fido. Le cas de La selva sin amor (1627)», Rivalités de plumes entre Espagne et Italie, $X V^{E}-X V I I^{e}$ siècles, París, Classiques Garnier, 2018, 93-134.

Morley, S. Griswold y Bruerton, Courtney, Cronología de las comedias de Lope de Vega. Con un examen de atribuciones dudosas, Madrid, Gredos, 1968.

Newels, Margaret, Los géneros dramáticos en las poéticas del Siglo de Oro, Londres, Tamesis, 1974.

NowICKI, Jürgen, «Juan Pablo Mártir Rizo: Plagiator des Giason Denores und Verteidiger Vergils", Spanische Literatur im Goldenen Zeitalter. Fritz Schalk zum 70. Geburtstag, Frankfurt am Main, Vittorio Klostermann, 1973, 357-393.

Oleza Simó, Joan, «La tradición pastoril y la práctica cortesana en Valencia, II: coloquios y señores", Teatros y prácticas escénicas, I. El Quinientos valenciano, dir. Juan Oleza Simó; coord. Manuel V. Diago Moncholí, Valencia, Institució Alfons el Magnànim, 1984, 243-257.

—, (con la colaboración de J. L. Sirera, M. V. Diago, J. L. Canet y J. J. Sánchez Escobar), "Hipótesis sobre la génesis de la comedia barroca», en Teatros y prácticas escénicas, I. El Quinientos valenciano, dir. Juan Oleza Simó; coord. Manuel V. Diago Moncholí, Valencia, Institució Alfons el Magnànim, 1984, 9-42.

—, "Los géneros en el teatro de Lope de Vega: el rumor de las diferencias», Del horror a la risa. Los géneros dramáticos clásicos. Homenaje a Christiane FaliuLacourt, ed. Ignacio Arellano, Víctor García Ruiz y Marc Vitse, Kassel, Edition Reichenberger, 1994, 235-250.

—, "The Arte nuevo from the authority of ancient art: the discussion of dramatic genres», From Ancient Classical to Modern Classical. Lope de Vega and the New Challenges of Spanish Theatre, Nueva York, Idea Books, 2012, 15-60. 
Oleza Simó, Joan y Antonucci, Fausta, «La arquitectura de los géneros en la "comedia nueva": diversidad y transformaciones», RILCE, 29.3 (2013), 698-741.

Pedraza Jiménez, Felipe B. y González Cañal, Rafael, ed., Lope de Vega: comedia urbana y comedia palatina. Actas de las XVIII Jornadas de teatro clásico (Almagro, julio de 1995), Almagro, Universidad de Castilla-La Mancha / Festival de Almagro 1996.

—, La comedia de enredo. Actas de las XX Jornadas de teatro clásico (Almagro, julio de 1997), Universidad de Castilla-La Mancha / Festival de Almagro, 1998.

Porqueras Mayo, Alberto, El prólogo en el Manierismo y Barroco españoles, Madrid, CSIC, 1968.

Rodríguez Mancho, Ricardo, «La teatralidad pastoril», Teatro y prácticas escénicas, I: El Quinientos valenciano, dir. Juan Oleza Simó; coord. Manuel V. Diago Moncholí, Valencia, Institució Alfons el Magnànim, 1984, 165-187.

Russo, Luigi, «La catarsi aristotelica e i suoi interpreti», Problemi di metodo critico, Bari, Laterza, 1950, 39-56.

Salomon, Noël, Lo villano en el teatro del Siglo de Oro, Castalia, Madrid, 1985. SAmpson, Lisa, Pastoral Drama in Early Modern Italy: the Making of a New Genre, Nueva York, Legenda, 2006.

Sánchez Escribano, Federico y Porqueras Mayo, Alberto, Preceptiva dramática española del Renacimiento y el Barroco, Madrid, Gredos, 1972.

SÁnChez LAílla, Luis, "Cauces y ámbitos de la reflexión sobre el drama en la España del Siglo de Oro», Rivista di filologia e letterature ispaniche, III (2000), 33-59.

—, "Sección V de la Nueva idea de la tragedia antigua o ilustración última al libro singular de Poética de Aristóteles Stagirita", Édition digital et étude de la polémique autour de Góngora (POLEMOS), dir. Mercedes Blanco, 21-03-19, $<$ http://obvil.paris-sorbonne.fr/corpus/gongora/1633_tragedia/>.

Schoell, Konrad, "Arkadische Dichtung als Comedia. Zu Lope de Vegas Schäferspielen», Texte, Kontexte, Strukturen. Festschrift zum 60. Geburtstag von Karl Alfred Blüher, Tübingen, Gunter Narr Verlag, 1987, 311-323.

Seidensticker, Bernd, Palintonos Harmonia. Studien zu komischen Elementen in der griechischen Tragödie, Göttingen, Vandenhoeck \& Ruprecht, 1982.

Trambaioli, Marcella, "Il pastor fido de Giovan Battista Guarini: paradigma privilegiado de la comedia cortesana en la España de los Austrias», Centros de poder italianos en la monarquía hispánica (siglos XV-XVIII), coord. José Martínez Millán y Manuel Rivera Rodríguez, Madrid, Ediciones Polifemo, 2010a, vol. II, 1337-1373.

—, "Lope de Vega frente a la tragicommedia de Giovan Battista Guarini», Cuatrocientos años del "Arte nuevo de hacer comedias" de Lope de Vega (Actas selectas del XIV Congreso de la Asociación Internacional de Teatro Español y Novohispano de los Siglos de Oro, Olmedo, 20 al 23 de julio de 2009), ed. Germán Vega García-Luengos y Héctor Urzaiz Tortajada, Salamanca, Ayuntamiento 
de Olmedo / Sociedad Estatal de Conmemoraciones Culturales, AINTENSO, Universidad de Valladolid, 2010b, 1013-1023.

—, "La escritura en colaboración en El pastor fido de Solís, Coello y Calderón», Calderón y su escuela: variaciones e innovación de un modelo teatral. XV Coloquio Anglogermano sobre Calderón (Wrodaw, 14-18 de julio de 2008), ed. Manfred Tietz y Gero Arnscheidt, en colaboración con Beata Baczynska Stuttgart, Stuttgart, Franz Steiner Verlag, 2011, 493-521.

—, "Lo trágico y lo cómico mezclado" en Il pastor fido de Giovan Battista Guarini y sus reescrituras españolas», Tragique et comique liés, dans le théâtre, de l'Antiquité à nos jours (du texte à la mise en scène). Actes du colloque organisé à l'Université de Rouen en abril 2012, ed. Milagros Torres, Ariane Ferry, Sofía Moncó Taracena y Daniel Lecler, Publications numériques du CÉRÉdI (Actes de colloques et journées d'étude, 7), 2012, 30-05-19, <http://ceredi. labos.univ-rouen.fr/public/?lo-tragico-y-lo-comico-mezclado-en.html>.

VITSE, Marc, Éléments pour une théorie du théâtre espagnol du XVII ime siècle, Toulouse, Presses Universitaires du Mirail, 1988.

—, "La epístola Al Apolo de España de Cascales y el Discurso apologético en aprobación de la comedia», El mundo del teatro español en su Siglo de Oro: Ensayos dedicados a John E. Varey, ed. J. M. Ruano de la Haza, Ottawa, Dovehouse, 1989, 119-136.

—, «La poética de la Comedia: estado de la cuestión o de la poética a las poéticas de la Comedia», La comedia. Seminario hispano-francés organizado por la Casa de Velázquez. (Madrid, diciembre 1991-junio 1992), ed. Jean Canavaggio, Madrid, Casa de Velázquez, 1995, 273-289.

WeInberg, Bernard, A History of Literary Criticism in the Italian Renaissance, Chicago, The University of Chicago Press, 1961, 2 vols.

—, Trattati di poetica e retorica del Cinquecento, Bari, Laterza, 1972, vol. III. 
